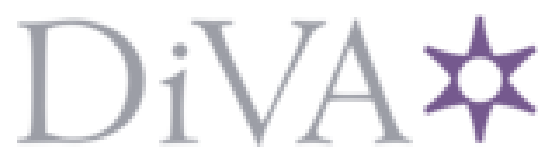

http://www.diva-portal.org

\title{
Postprint
}

This is the accepted version of a paper published in European Journal of Nuclear Medicine and Molecular Imaging. This paper has been peer-reviewed but does not include the final publisher proofcorrections or journal pagination.

Citation for the original published paper (version of record):

Orlova, A., Hofström, C., Strand, J., Varasteh, Z., Sandström, M. et al. (2013)

$\left[{ }^{99 \mathrm{~m}} \mathrm{Tc}(\mathrm{CO})_{3}\right]^{+}-(\mathrm{HE})_{3}-\mathrm{Z}_{\text {IGF IR:4551 }}$, a new Affibody conjugate for visualization of insulin-like growth factor-1 receptor expression in malignant tumours.

European Journal of Nuclear Medicine and Molecular Imaging, 40(3): 439-449

http://dx.doi.org/10.1007/s00259-012-2284-8

Access to the published version may require subscription.

N.B. When citing this work, cite the original published paper.

Permanent link to this version:

http://urn.kb.se/resolve?urn=urn:nbn:se:uu:diva- 196212 
The final publication is available at Springer via http://dx.doi.org/10.1007/s00259-012-2284-8

\section{$\left[{ }^{99 \mathrm{~m}} \mathrm{Tc}(\mathrm{CO})_{3}\right]^{+}-(\mathrm{HE})_{3}-\mathrm{Z}_{\mathrm{IGF1R}: 4551}$, a new affibody conjugate for visualization of}

\section{insulin-like growth factor 1 receptor expression in malignant tumours}

Anna Orlova ${ }^{1}$, Camilla Hofström ${ }^{2}$, Joanna Strand ${ }^{3}$, Zoherh Varasteh ${ }^{1}$, Mattias Sandstrom ${ }^{4}$, Karl

Andersson $^{3,5}$, Vladimir Tolmachev ${ }^{3}$, Torbjörn Gräslund ${ }^{1}$

${ }^{1}$ Preclinical PET Platform, Department of Medicinal Chemistry, Uppsala University, Sweden;

${ }^{2}$ Division of Molecular Biotechnology, School of Biotechnology, Royal Institute of Technology, Stockholm, Sweden;

${ }^{3}$ Division of Biomedical Radiation Sciences, Uppsala University, Sweden.

${ }^{4}$ Medical Physics, Department of Oncology, Uppsala University Hospital, Uppsala, Sweden

${ }^{5}$ Ridgeview Instruments AB, Uppsala, Sweden

Corresponding author:

Vladimir Tolmachev

Biomedical Radiation Sciences

Rudbeck Laboratory

Uppsala University

SE-751 85 Uppsala

Sweden

Phone: +46184713414

Fax: +46184713432

E-mail: vladimir.tolmachev@bms.uu.se

Key words: affibody molecules; molecular imaging; technetium-99m; HEHEHE-tag; IGF-1R; biodistribution 


\begin{abstract}
Purpose. Radionuclide imaging of insulin-like growth factor type 1 receptor (IGF-1R) expression in tumors might be used for selection of patients who would benefit from IGF-1R targeted therapy. We have earlier shown the feasibility of IGF-1R imaging using the ${ }^{111}$ InDOTA-His 6 - $\mathrm{Z}_{\mathrm{IGF1R}: 4551}$ affibody molecule. The use of ${ }^{99 \mathrm{~m}} \mathrm{Tc}$ instead of ${ }^{111} \mathrm{In}$ should improve sensitivity and resolution of imaging, and reduce dose burden to patients. We hypothesized that inclusion of a HEHEHE-tag instead of a His ${ }_{6}$-tag in $\mathrm{Z}_{\text {IGF1R:4551 }}$ would permit its convenient purification using IMAC, enable labelling with $\left[{ }^{99 \mathrm{~m}} \mathrm{Tc}(\mathrm{CO})_{3}\right]^{+}$, and improve its biodistribution.
\end{abstract} Methods. Z Z IGF1R:4551 was expressed with a HEHEHE-tag in the N-terminus. The resulting $(\mathrm{HE})_{3}-\mathrm{Z}_{\mathrm{IGF1R}: 4551}$ construct was labelled with $\left[{ }^{99 \mathrm{~m}} \mathrm{Tc}(\mathrm{CO})_{3}\right]^{+}$. Targeting of IGF-1R expressing cells using $\left[{ }^{99 \mathrm{~m}} \mathrm{Tc}(\mathrm{CO})_{3}\right]^{+}-(\mathrm{HE})_{3}-\mathrm{Z}_{\mathrm{IGF} 1 \mathrm{R}: 4551}$ was evaluated in vitro and in vivo.

Results. (HE) ${ }_{3}-Z_{\text {IGF1R:4551 }}$ can be stably labeled with ${ }^{99 \mathrm{~m}} \mathrm{Tc}$ with preserved specific binding to IGF-1R expressing DU-145 prostate cancer cells in vitro. In mice, $\left[{ }^{99 \mathrm{~m}} \mathrm{Tc}(\mathrm{CO})_{3}\right]^{+}-(\mathrm{HE})_{3^{-}}$ $\mathrm{Z}_{\mathrm{IGF1R}: 4551}$ accumulated in IGF-1R-expressing organs (pancreas, stomach, lung and salivary gland). $\left[{ }^{99 \mathrm{~m}} \mathrm{Tc}(\mathrm{CO})_{3}\right]^{+}-(\mathrm{HE})_{3}-\mathrm{Z}_{\mathrm{IGF1R}: 4551}$ demonstrated 3.6-fold lower accumulation in liver and spleen in comparison with ${ }^{111}$ In-DOTA-Z $\mathrm{IGF1R}_{\text {4551. }}$ In NMRI nu/nu mice with DU-145 prostate cancer xenografts, the tumor uptake was $1.32 \pm 0.11 \% \mathrm{ID} / \mathrm{g}$ and the tumor-to-blood ratio was $4.4 \pm 0.3$ at $8 \mathrm{~h}$ after injection. The xenografts were visualized by gamma-camera at $6 \mathrm{~h}$ after injection.

Conclusion. $\left.{ }^{99 \mathrm{~m}} \mathrm{Tc}(\mathrm{CO})_{3}\right]^{+}-(\mathrm{HE})_{3}-\mathrm{Z}_{\mathrm{IGF1R}: 4551}$ is a promising candidate for visualization of IGF$1 \mathrm{R}$ expression in malignant tumours. 


\section{INTRODUCTION}

The insulin-like growth factor-1 receptor (IGF-1R) is a transmembrane tyrosine kinase, involved in activation of mitogenic and antiapoptotic cellular signalling pathways [1]. Both pre-clinical and clinical data suggest that IGF-1R signalling acts as a pro-survival factor for several types of cancers, including breast, prostate, lung, colorectal, endometrial and bladder carcinomas and sarcomas, where its upregulated expression confers resistance to different chemotherapeutic, hormonal and targeted therapies [1-5]. This creates a rationale to target and deactivate IGF-1R as a potential approach for cancer therapy [6]. Several IGF-1R targeting drugs are under preclinical and clinical development $[7,8]$ where the main strategies to deactivate signalling include receptor blockade, kinase inhibition and ligand sequestration. Currently, IGF-1R blockade by a monoclonal antibody is the most common approach in clinical trials [7]. Particularly in prostate cancer, inhibition of IGF-1R-signalling is regarded as a promising methodology for treatment of androgen independent prostate cancer $[9,10]$, because excessive signalling of IGF-1R leads to activation of androgen receptors in the absence of androgens, i.e. it causes androgen independence.

Reports from clinical trials emphasize that identification of predictive biomarkers and careful patient stratification are required for successful IGF-1R-targeted treatment [11-13]. Pre-clinical data demonstrated that a higher level of membranous IGF-1R is associated with response to IGF1R inhibitors [14]. Clinical data also suggest that the response to the anti-IGF-1R antibody CP751,871 correlates with high membranous expression of IGF-1R [15]. This creates a rationale for radionuclide molecular imaging of extracellular domain of IGF-1R for patient stratification for therapy using blocking antibodies. Indeed, pre-clinical studies have demonstrated that imaging of IGF-1R can be used to predict the response to anti-IGF-1R antibody therapy of bone sarcoma [16] and IFG-1R-mediated resistance to trastuzumab therapy in breast cancer [17]. 
It has to be noted that the level IGF-1R expression, which is associated with response to therapy, is rather low (10000-30000 receptors per cell) $[18,19]$. In addition, there is normal physiological IGR-1R expression in a number of tissues, such as colon, lung, pancreas, salivary gland, and stomach (http://www.proteinatlas.org). A combination of low expression in tumours and ubiquitous expression in normal tissues makes radionuclide imaging of IGF-1R challenging and prompts for the search for the optimal format of an imaging probe.

Affibody molecules are a relatively new class of targeting proteins based on protein A [20]. A small size (58 amino acids, $7 \mathrm{kDa}$ ) and usually high specificity and affinity (from low nanomolar to subnanomolar) make them attractive as imaging probes. Their excellent potential for radionuclide imaging of cancer-associated molecular targets has been shown in a number of preclinical [20] and a clinical study [21]. The feasibility of specific in vivo radionuclide imaging of IGF-1R expression using the ${ }^{111}$ In-[MMA-DOTA-Cys ${ }^{61}$ ]-His ${ }_{6}-Z_{\text {IGF1R:4551 }}$ affibody molecule has also recently been demonstrated [22].

The current study presents further development of $\mathrm{Z}_{\mathrm{IGF1R}: 4551}$ for imaging. Substitution of ${ }^{111} \mathrm{In}$ for ${ }^{99 \mathrm{~m}} \mathrm{Tc}$ should allow improved spatial resolution, and in this way, sensitivity, of imaging. The use of ${ }^{99 \mathrm{~m}} \mathrm{Tc}$ would also allow for a decreased dose burden to the patient, and to appreciably reduce costs of imaging procedures. Furthermore, the previous generation of the imaging probe contained a hexahistidine-tag (His ${ }_{6}$-tag) to facilitate purification of recombinantly produced $\mathrm{Z}_{\text {IGF1R:4551 }}$ by immobilized metal ion affinity chromatography (IMAC). In a parallel study we have found that the use of histidine-glutamate-histidine-glutamate-histidine-glutamate-tag (HEHEHE-tag) instead of a His ${ }_{6}$-tag permits purification of anti-HER2 affibody molecules by IMAC, enables their convenient site-specific labelling with $\left[{ }^{99 \mathrm{~m}} \mathrm{Tc}(\mathrm{CO})_{3}\right]^{+}$, and improves their biodistribution by reducing hepatic accumulation of radioactivity [23]. We hypothesized that replacement of the His $_{6}$-tag with a HEHEHE-tag in $\mathrm{Z}_{\text {IGF1R:4551 would similarly permit convenient }}$ purification using IMAC, enable labelling with $\left[{ }^{99^{\mathrm{m}}} \mathrm{Tc}(\mathrm{CO})_{3}\right]^{+}$, and improve its biodistribution. 


\section{MATERIALS AND METHODS}

\section{Materials}

${ }^{99 \mathrm{~m}} \mathrm{Tc}$ was obtained as pertechnetate from an Ultra-TechneKow generator (Covidien) by elution with $0.9 \% \mathrm{NaCl}$. The IsoLink kit was kindly provided by Covidien. Radioactivity was measured using a gamma-counter with a 3-inch $\mathrm{NaI}(\mathrm{Tl})$ detector (1480 WIZARD, PerkinElmer). The purity of non-labelled Affibody molecules was determined using reversed phase HPLC. The purity of radiolabeled Affibody molecules was determined by radio-ITLC (150-771 Tec-Control Chromatography, Biodex Medical Systems) sodium dodecyl sulphate polyacrylamide gel electrophoresis (SDS-PAGE). The distribution of radioactivity along ITLCstrips and SDS-PAGE gels was measured on a Cyclone ${ }^{\mathrm{TM}}$ Storage Phosphor System (PerkinElmer). The purity of all studied compounds was over 95\%. Data on cellular uptake and biodistribution were assessed by an unpaired, two-tailed $t$-test using GraphPad Prism program (GraphPad Software, CA) to determine any significant differences $(\mathrm{p}<0.05)$.

\section{Production, purification and characterization of the $(\mathrm{HE})_{3}-Z_{I G F 1 R: 4551}$ Affibody molecule}

The production and purification of (HE) ${ }_{3}-Z_{\mathrm{IGF1R}: 4551}$ Affibody molecule was made essentially as previously described [24]. Briefly, PCR fragment encoding for (HE) $)_{3}-Z_{\text {IGF1R:4551 was sub-cloned }}$ into the expression vector pET21a(+) (Novagen, Germany) and the correct DNA sequence was verified by DNA-sequencing. The Affibody molecule was expressed in Escherichia coli strain BL21(DE3) and was recovered by IMAC using a Talon Metal Affinity Resin (BD Bioscience, CA) as previously described [25].

The (HE) $)_{3}-Z_{\text {IGF1R:4551 }}$ Affibody molecule was further purified by reverse phase high-performance liquid chromatography (RP-HPLC) on an Agilent 1200 HPLC system (Agilent Technologies, CA). The sample was injected onto a C18 column using a 20 min gradient of 20-65\% B (A: 
$0.1 \%$ TFA- $\mathrm{H}_{2} \mathrm{O}$, B: $0.1 \%$ TFA- $\mathrm{CH}_{3} \mathrm{CN}$ ), with a flow rate of $2.5 \mathrm{ml} / \mathrm{min}$. The final purity of

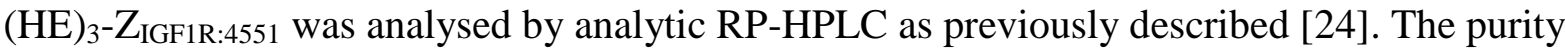
was determined by dividing the area of the peak corresponding to the Affibody molecule with the total area of all peaks in the chromatogram. The protein concentration was determined by amino acid analysis (Amino Acid Analysis Center, Uppsala University).

\section{Circular dichroism}

Circular dichroism spectra of (HE) $)_{3}-Z_{\text {IGF1R:4551 }}$ at a concentration of $60 \mu \mathrm{M}$ in PBS, was recorded from 250 to $195 \mathrm{~nm}$ at $20^{\circ} \mathrm{C}$ using a JASCO J-810 spectropolarimeter instrument (JASCO, Japan). For variable temperature measurements the absorbance at $221 \mathrm{~nm}$ was recorded as a function of increasing temperature from $20^{\circ} \mathrm{C}$ to $90^{\circ} \mathrm{C}\left(5^{\circ} \mathrm{C} / \mathrm{min}\right)$.

\section{Biosensor analysis}

Affinity constants were determined by SPR analysis on a Biacore 3000 instrument (GE Healthcare AB, Sweden) using a single-cycle kinetic method. The extracellular domains of human and mouse IGF-1R (R\&D systems, Minneapolis, MN, USA) were immobilized (600 RU and 1500 RU, respectively) on different flow-cell surfaces of a CM5 chip (Biacore Life Science,

GE Healthcare, Uppsala, Sweden) using amine coupling, according to the manufacturer's instructions. A 4-fold dilution series comprised of five different concentrations was prepared and consecutively injected over the flow-cell surfaces, with increasing concentrations ranging from 1.31 to $336 \mathrm{nM}$ using a flow rate of $30 \mu \mathrm{l} / \mathrm{ml}$. The initial analysis of obtained sensorgrams was performed using Biacore evaluation software (Biacore Life Science, GE Healthcare, Uppsala, Sweden). For detailed analysis, the sensorgrams were subjected to the distribution based interaction analysis using the Interaction Map tool [26] in TraceDrawer 1.4 software (Ridgeview Instruments AB, Sweden). 


\section{Labelling and in vitro stability}

Labelling of $(\mathrm{HE})_{3}-\mathrm{Z}_{\mathrm{IGF1R}: 4551}$ with [ $\left.{ }^{99 \mathrm{~m}} \mathrm{Tc}(\mathrm{CO})_{3}\right]^{+}$was performed as described earlier [27]. Briefly, $500 \mu \mathrm{l}(200-320 \mathrm{MBq})$ of ${ }^{99} \mathrm{TcO}_{4}{ }^{-}$-containing generator eluate were added to a vial with the IsoLink kit. The mixture was incubated at $100^{\circ} \mathrm{C}$ during $20 \mathrm{~min}$. Thereafter, $40 \mu \mathrm{l}$ of mixture were transferred to a tube containing $50 \mu \mathrm{g}(\sim 6.8 \mathrm{nmol})$ Affibody molecule in $40 \mu \mathrm{L}$ PBS and incubated at $50^{\circ} \mathrm{C}$ for $60 \mathrm{~min}$. The labelled affibody molecule was purified using sizeexclusion NAP-5 columns (GE Healthcare, Sweden), pre-equilibrated and eluted with PBS. The purity of each preparation was evaluated using radio-ITLC.

To predict in vivo stability, two samples of $\left[{ }^{99 \mathrm{~m}} \mathrm{Tc}(\mathrm{CO})_{3}\right]^{+}-(\mathrm{HE})_{3}-\mathrm{Z}_{\mathrm{IGF1R}: 4551}$ were incubated at $37^{\circ} \mathrm{C}$ with murine serum for one hour. The concentration was selected to mimic concentration in murine blood immediately after injection. After incubation, samples were analysed by SDSPAGE on a NuPAGE 4-12\% Bis-Tris Gel (Invitogen) in MES buffer (200 V constant). Two control samples of the same conjugate, which were stored in PBS at room temperature, were analysed together with the test samples on the same gel.

\section{In vitro cell binding and processing of $\left[{ }^{99 m} \mathrm{Tc}(\mathrm{CO})_{3}\right]^{+}-(\mathrm{HE})_{3}-Z_{I G F 1 R: 4551}$}

The specificity of $\left[{ }^{99 \mathrm{~m}} \mathrm{Tc}(\mathrm{CO})_{3}\right]^{+}-(\mathrm{HE})_{3}-\mathrm{Z}_{\mathrm{IGF} 1 \mathrm{R}: 4551}$ for binding to IGF-1R-expressing cells was evaluated using the DU-145 prostate cancer cell line (American Type Tissue Culture Collection). An in vitro specificity test was performed according to the methods described earlier [22]. Briefly, a solution of $\left[{ }^{99 \mathrm{~m}} \mathrm{Tc}(\mathrm{CO})_{3}\right]^{+}-(\mathrm{HE})_{3}-\mathrm{Z}_{\mathrm{IGF1R}: 4551}(10 \mathrm{nM})$ was added to 6 Petri dishes (approx. $10^{6}$ cells in each). For blocking, a 100-fold excess of non-labelled (HE) $)_{3}-Z_{\text {IGF1R:4551 was }}$ added 15 min before radiolabeled conjugates to saturate the receptors. The cells were incubated during two hours in a humidified incubator at $37^{\circ} \mathrm{C}$. Thereafter, the media was collected, the cells were detached by a trypsin-EDTA solution (0.25\% trypsin, $0.02 \%$ EDTA, Biochrom AG, Berlin, Germany), and the radioactivity in cells and media was measured, to determine cellbound radioactivity fraction. 
A measurement of the rate of internalization of $\left[{ }^{99 \mathrm{~m}} \mathrm{Tc}(\mathrm{CO})_{3}\right]^{+}-(\mathrm{HE})_{3}-\mathrm{Z}_{\mathrm{IGF} 1 \mathrm{R}: 4551}$ by DU-145 cells was performed according to the method described earlier [22]. Briefly, the cells (approx. $10^{6}$ per dish) were incubated with the labelled compound $(1.5 \mathrm{nM})$ at $37^{\circ} \mathrm{C}$. At pre-determined time points $(1,2,3,4,8$ and $24 \mathrm{~h}$ after incubation start), the medium from a set of three dishes was removed. To collect the membrane-bound radioactivity, the cells were treated with $0.2 \mathrm{M}$ glycine buffer containing $4 \mathrm{M}$ urea, $\mathrm{pH} 2.5$, for 5 min on ice. To collect radioactivity internalized by the cells, treatment with $1 \mathrm{M} \mathrm{NaOH}$ at $37^{\circ} \mathrm{C}$ for $0.5 \mathrm{~h}$ was performed. The percentage of internalized radioactivity was calculated for each time point.

To measure the affinity of $\left[{ }^{99 \mathrm{~m}} \mathrm{Tc}(\mathrm{CO})_{3}\right]^{+}-(\mathrm{HE})_{3}-\mathrm{Z}_{\mathrm{IGF} 1 \mathrm{R}: 4551}$ for DU-145 cells, the cells were incubated for $4 \mathrm{~h}$ at $4^{\circ} \mathrm{C}$ with radiolabeled affibody molecule at concentrations from 0.08 to $27 \mathrm{nM}$ in complete medium. For each data point, four dishes were used, including one pre-saturated with unlabeled (HE) $)_{3}-Z_{\text {IGF1R:4551 }}$ at $3.7 \quad M$ to determine unspecific binding. After incubation, the medium was aspirated, and the cells were detached by trypsin-EDTA solution and counted using an automatic cell counter (Beckman Coulter). Radioactivity of the samples was measured. The data were analysed using GraphPad Prism software (GraphPad Software, San Diego, CA, USA).

\section{In vivo studies}

All animal experiments were planned and performed in accordance with national legislation on laboratory animals' protection and were approved by the Ethics Committee for Animal Research in Uppsala. For xenografting, $5 \times 10^{6}$ DU-145 cells (in Matrigel ${ }^{\circledR}$, BD Biosciences, $50 \%$ in PBS) were subcutaneously implanted in the right hind leg of Balb/C nu/nu mice. Xenografts were allowed to grow for 2 weeks. 
Comparative biodistribution of $\left[^{99 m} \mathrm{Tc}(\mathrm{CO})_{3}\right]^{+}-(\mathrm{HE})_{3}-Z_{\text {IGF1R:4551 }}$ and ${ }^{111}$ In-DOTA-His $\sigma^{-}$

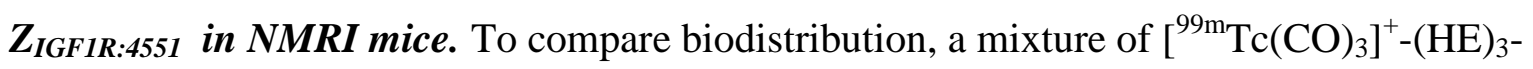
$\mathrm{Z}_{\mathrm{IGF1R}: 4551}\left(400 \mathrm{kBq}\right.$ per mouse) and ${ }^{111} \mathrm{In}-$ DOTA- His ${ }_{6}-\mathrm{Z}_{\mathrm{IGF1R}: 4551}(10 \mathrm{kBq}$ per mouse) in $100 \mu \mathrm{l}$ PBS was intravenously injected in male NMRI mice (average weight $33.5 \pm 2.4 \mathrm{~g}$ ). The total injected protein dose was adjusted by dilution with non-labelled (HE) $)_{3}-Z_{\mathrm{IGF1R}: 4551}$ to $1 \mu \mathrm{g}$ per mouse. At 1, 4 and 24 h p.i., a group of four mice was sacrificed by injection of a lethal dose of anaesthesia (20 $\mu \mathrm{l}$ of solution per gram of body weight: Ketalar (Pfizer):50 mg/ml, Rompun (Bayer) :20 mg/ml) followed by heart puncture and exsanguination with a syringe rinsed with heparine (5000 IE/ml, Leo Pharma). Samples of blood, colon, lung, liver, spleen, pancreas, kidney, muscle and bone were collected, weighed and their radioactivity was measured. In addition, gastrointestinal tract with its content was collected to estimate hepatobiliary excretion of radioactivity. Whole gamma-spectrum was recorded for each sample. Technetium-99m radioactivity was measured in the energy range of $20-150 \mathrm{keV}$, and indium-111 in the range of 150-480 keV. The data were corrected for dead time, background and spillover. Tissue uptake was calculated as per cent of injected dose per gram (\% ID/g). A paired $t$-test was used to find a significant difference $(\mathrm{p}<0.05)$ in biodistribution of conjugates.

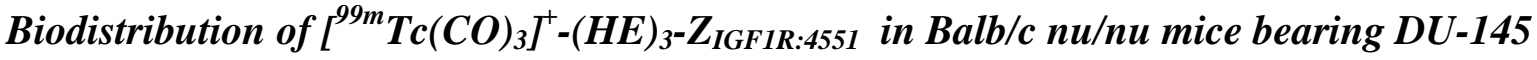 prostate cancer xenografts.}

At the time of probe injection, the average animal weight was $21.5 \pm 0.9 \mathrm{~g}$, and the average tumour weight was $0.21 \pm 0.07 \mathrm{~g}$. The mice were randomly distributed into 3 groups and injected with $400 \mathrm{kBq}$ of $\left[{ }^{99 \mathrm{~m}} \mathrm{Tc}(\mathrm{CO})_{3}\right]^{+}-(\mathrm{HE})_{3}-\mathrm{Z}_{\mathrm{IGF} 1 \mathrm{R}: 4551}$ in $100 \mu \mathrm{l}$ PBS. The injected protein dose was adjusted by dilution with non-labelled (HE) $)_{3} \mathrm{Z}_{\mathrm{IGF} 1 \mathrm{R}: 4551}$ to $1 \mu \mathrm{g}$ per mouse. At 4,8 and $24 \mathrm{~h}$ p.i., a group of four mice was sacrificed by anaesthesia overdosing followed by exsanguination. Tumours as well as samples of tissues were collected and weighed. Radioactivity of samples was 
measured in the 90-160 keV energy window. Tissue uptake was calculated as percent of injected dose per gram $(\% \mathrm{ID} / \mathrm{g})$.

\section{Comparative biodistribution of $\left[^{99 m} \mathrm{Tc}(\mathrm{CO})_{3}\right]^{+}-(\mathrm{HE})_{3}-\mathrm{Z}_{\text {IGF1R:455I }}$ and ${ }^{111}$ In-DOTA-His $\sigma^{-}$}

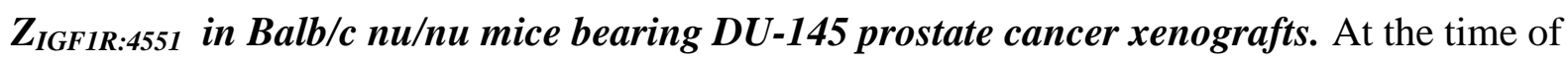
the experiment, the average animal weight was $22.5 \pm 0.7 \mathrm{~g}$ and the average tumour weight was $0.4 \pm 0.1 \mathrm{~g}$. Eight mice were randomly divided into two groups. To test the in vivo binding specificity, one group of mice was injected with $300 \mu \mathrm{g}$ non-labelled (HE) $)_{3}-\mathrm{Z}_{\mathrm{IGF1R}: 4551} 40 \mathrm{~min}$ before injection of labelled compounds in order to pre-saturate IGF-1R receptors. A mixture of $\left[{ }^{99 \mathrm{~m}} \mathrm{Tc}(\mathrm{CO})_{3}\right]^{+}-(\mathrm{HE})_{3}-\mathrm{Z}_{\mathrm{IGF} 1 \mathrm{R}: 4551}(50 \mathrm{kBq}$ per mouse $)$ and ${ }^{111} \mathrm{In}-$ DOTA- His 6 - $\mathrm{Z}_{\mathrm{IGF} 1 \mathrm{R}: 4551}(10 \mathrm{kBq}$ per mouse) in $100 \mu$ l PBS per mouse was intravenously injected in each mouse. The total injected protein dose was adjusted by dilution with non-labelled (HE) $)_{3}-Z_{\text {IGF1R:4551 }}$ to $1 \mu \mathrm{g}$ per mouse. The mice were sacrificed at $6 \mathrm{~h}$ p.i., and biodistribution of $\left[{ }^{99 \mathrm{~m}} \mathrm{Tc}(\mathrm{CO})_{3}\right]^{+}-(\mathrm{HE})_{3^{-}}$ $\mathrm{Z}_{\mathrm{IGF1R}: 4551}$ and ${ }^{111}$ In-DOTA-His ${ }_{6}-\mathrm{Z}_{\mathrm{IGF1R}: 4551}$ was measured as described above. A paired $t$-test was used to find a significant difference $(\mathrm{p}<0.05)$ in biodistribution of conjugates. For determination of saturation effect, an unpaired test was used.

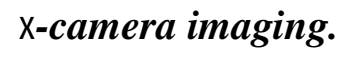

Two mice with DU-145 xenografts $\left(0.9-1.0 \mathrm{~cm}^{3}\right)$ were injected with $\left[{ }^{99 \mathrm{~m}} \mathrm{Tc}(\mathrm{CO})_{3}\right]^{+}-(\mathrm{HE})_{3^{-}}$ $\mathrm{Z}_{\mathrm{IGF1R}: 4551}(3 \mathrm{MBq}, 1 \mu \mathrm{g}$, in $100 \mu \mathrm{PBS})$ and imaging was performed $6 \mathrm{~h}$ later. Immediately before imaging, the animals were sacrificed by anaesthesia overdosing. After euthanasia, the urine bladders were excised. The imaging experiment was performed using a GE Infinia gamma camera equipped with a low energy high resolution (LEHR) collimator. Static images (30 min) were obtained with a zoom factor of 2 in a $256 \times 256$ matrix. The evaluation of the images was performed using Osiris 4.19 software (University Hospital of Geneva, Switzerland). In each animal, a region of interest (ROI) was drawn around the tumour. The same region was copied to 
a contralateral thigh. Tumour-to-contralateral thigh ratios were calculated based on average counts in the ROIs. 


\section{RESULTS}

\section{Production, purification and characterization of the $(\mathrm{HE})_{3}-Z_{I G F 1 R: 4551}$ Affibody molecule}

$(\mathrm{HE})_{3}-\mathrm{Z}_{\mathrm{IGF1R}: 4551}$ was recombinantly expressed in Escherichia coli under control of the T7promoter. After harvest, the lysate containing $(\mathrm{HE})_{3}-\mathrm{Z}_{\mathrm{IGF1R}: 4551}$ was heat-treated for $10 \mathrm{~min}$ at $60^{\circ} \mathrm{C}$ to precipitate a portion of endogenous E. coli proteins prior to IMAC purification on an affinity resin containing immobilized $\mathrm{Co}^{2+}$. The $(\mathrm{HE})_{3}-\mathrm{Z}_{\mathrm{IGF1R}: 4551}$ Affibody molecule was successfully recovered by IMAC, and was further purified by RP-HPLC. Analysis by SDSPAGE of a sample taken after RP-HPLC showed only a single band having a molecular weight corresponding to the expected molecular mass of (HE) $)_{3} \mathrm{Z}_{\mathrm{IGF1R}: 4551}$ (Figure 1A). LC-MS analysis confirmed the molecular weight of the recovered protein (calculated molecular weight of $(\mathrm{HE})_{3^{-}}$ $\mathrm{Z}_{\mathrm{IGF1R}: 4551}$ is $7463 \mathrm{Da}$, found molecular weight was $7464 \mathrm{Da}$ ), (Figure 1C), and RP-HPLC analysis demonstrated an exceptional purity of 99\% (Figure 1B).

The secondary structure of (HE) $)_{3}-Z_{\text {IGF1R:4551 was investigated by circular dichroism. As }}$ expected, (HE) 3 $_{\text {IGF1R:4551 }}$ gave a CD-spectrum showing high alpha-helical content (Figure 2A) similar to the spectrum recorded previously for the similar affibody construct $\left(\mathrm{His}_{6}\right)-\mathrm{Z}_{\mathrm{IGF1R}: 4551}$ [22]. Also, the spectra recorded for $(\mathrm{HE})_{3}-Z_{\text {IGF1R:4551 }}$ before and after heating to $90^{\circ} \mathrm{C}$ were highly similar, indicating that the construct was able to completely refold after thermal denaturation. The melting temperature of $(\mathrm{HE})_{3}-\mathrm{Z}_{\mathrm{IGF} 1 \mathrm{R}: 4551}$ was determined to $58^{\circ} \mathrm{C}$ (Figure 2B).

The interaction kinetics between (HE) $)_{3}-\mathrm{Z}_{\mathrm{IGF1R}: 4551}$ and human or mouse IGF-1R was analysed on a Biacore 2000 instrument using single-cycle injection. The evaluation of the sensorgrams did not reflect a one-to-one interaction event between $(\mathrm{HE})_{3}-\mathrm{Z}_{\mathrm{IGF1R}: 4551}$ and the receptors. $\mathrm{A}$ heterogeneous ligand interaction model, indicating two independent binding events occurring, reflected the observed interaction better but not sufficiently good. Interaction Map analysis revealed two well defined processes for both receptors. For the human receptor (Figure 2C), 
peak 1 contributes to approximately $68 \%$ of the signal and is represented with average rate constants $\mathrm{k}_{\mathrm{a}}=1.50 \times 10^{4} \mathrm{M}^{-1} \mathrm{~s}^{-1}$ and $\mathrm{k}_{\mathrm{d}}=2.45 \times 10^{-5} \mathrm{~s}^{-1}$, which corresponds to a $\mathrm{K}_{\mathrm{D}}$ value of 1.63 nM. Peak 2 contributes to approximately $24 \%$ of the signal and is represented with average rate constants $\mathrm{k}_{\mathrm{a}}=1.43 \times 10^{6} \mathrm{M}^{-1} \mathrm{~s}^{-1}$ and $\mathrm{k}_{\mathrm{d}}=7.79 \times 10^{-5} \mathrm{~s}^{-1}$, which corresponds to a $\mathrm{K}_{\mathrm{D}}$ value of 54 $\mathrm{pM}$. The interaction of $(\mathrm{HE})_{3}-\mathrm{Z}_{\mathrm{IGF1R}: 4551}$ and mouse IGF-1R had similar heterogeneity $(72 \%$ and $22 \%$ for peak 1 and 2 , respectively) corresponding to similar affinities (1.43 nM and $25 \mathrm{pM})$ (Figure 2D).

\section{Labelling and in vitro stability of $\left[^{99 m} \mathrm{Tc}(\mathrm{CO})_{3}\right]^{+}-(\mathrm{HE})_{3}-\mathrm{Z}_{\text {IGF1R:4551 }}$}

Radiolabelling of $(\mathrm{HE})_{3}-\mathrm{Z}_{\mathrm{IGF1R}: 4551}$ with $\left[{ }^{99 \mathrm{~m}} \mathrm{Tc}(\mathrm{CO})_{3}\right]^{+}$was efficient, with a yield of $69 \pm 7 \%$. Simple purification using a disposable size-exclusion column resulted in a radiochemical purity of $99.1 \pm 0.9 \%$. An isolated radiochemical yield of $64 \pm 6 \%$ was achieved. Figure 3 shows the result of a stability test where $\left[{ }^{99 \mathrm{~m}} \mathrm{Tc}(\mathrm{CO})_{3}\right]^{+}-(\mathrm{HE})_{3}-\mathrm{Z}_{\mathrm{IGF1R}: 4551}$ was found to be very stable with a purity of $97.7 \pm 0.6 \%$ after a $1 \mathrm{~h}$ long incubation in murine serum at $37^{\circ} \mathrm{C}$.

\section{In vitro binding and processing of $\left[^{99 m} \mathrm{Tc}(\mathrm{CO})_{3}\right]^{+}-(\mathrm{HE})_{3}-Z_{I G F 1 R: 4551}$ by DU145 cells}

Binding specificity tests were performed to assess if the binding of $\left[{ }^{99 \mathrm{~m}} \mathrm{Tc}(\mathrm{CO})_{3}\right]^{+}-(\mathrm{HE})_{3}{ }^{-}$ $\mathrm{Z}_{\mathrm{IGF1R}: 4551}$ to living IGF-1R-expressing cells was receptor mediated. Saturation of the receptors by pre-incubation with non-labelled $(\mathrm{HE})_{3}-\mathrm{Z}_{\mathrm{IGF1R}: 4551}$ significantly $(\mathrm{p}<0.05)$ decreased the binding of the radiolabeled affibody molecule, which suggests that the binding was specific to the receptor (Figure $\mathbf{4 A}$ ).

Data concerning binding and internalization of $\left[{ }^{99 \mathrm{~m}} \mathrm{Tc}(\mathrm{CO})_{3}\right]^{+}-(\mathrm{HE})_{3}-\mathrm{Z}_{\mathrm{IGF} 1 \mathrm{R}: 4551}$ by the prostate cancer DU-145 cell line are presented in Figure 4B. For binding, a rapid phase of $1 \mathrm{~h}$ was found, followed by slower phase and a plateau was reached after $8 \mathrm{~h}$ of incubation. The internalization of $\left[{ }^{99 \mathrm{~m}} \mathrm{Tc}(\mathrm{CO})_{3}\right]^{+}-(\mathrm{HE})_{3}-\mathrm{Z}_{\mathrm{IGF1R}: 4551}$ was relatively inefficient, with a slow increase of the 
internalized fraction from $31 \pm 2 \%$ of the total cell-associated radioactivity after $1 \mathrm{~h}$ incubation to $52 \pm 1 \%$ after $24 \mathrm{~h}$.

According to a saturation assay, the DU-145 cells expressed $36,000 \pm 3,000$ binding sites per cell, and binding affinity (dissociation constant) of $\left[{ }^{99 \mathrm{~m}} \mathrm{Tc}(\mathrm{CO})_{3}\right]^{+}-(\mathrm{HE})_{3}-\mathrm{Z}_{\mathrm{IGF1R}: 4551}$ to the cells was $1.7 \mathrm{nM}$ (Figure 5).

\section{In vivo studies}

Comparative biodistribution of $\left[^{99 m} \mathrm{Tc}(\mathrm{CO})_{3}\right]^{+}-(\mathrm{HE})_{3}-\mathrm{Z}_{\text {IGF1R:4551 }}$ and ${ }^{111} \mathrm{In}-\mathrm{DOTA}-\mathrm{His}_{6^{-}}$

\section{$Z_{I G F I R: 4551}$ in NMRI mice.}

Data concerning biodistribution of $\left[{ }^{99 \mathrm{~m}} \mathrm{Tc}(\mathrm{CO})_{3}\right]^{+}-(\mathrm{HE})_{3}-\mathrm{Z}_{\text {IGF1R:4551 }}$ and ${ }^{111} \mathrm{In}$ - DOTA- His $6^{-}$ $\mathrm{Z}_{\mathrm{IGF1R}: 4551}$ in NMRI mice at 1, 4 and $24 \mathrm{~h}$ pi are presented in Figure 6. Biodistribution of both compounds was characterized by rapid renal clearance from blood and normal tissues.

Radioactivity accumulation in gastrointestinal tract (a measure for hepatobiliary excretion) was, less than $7 \%$ of injected radioactivity) for both conjugates (data not shown). Blood clearance of ${ }^{111}$ In was slightly faster than for ${ }^{99 \mathrm{~m}} \mathrm{Tc}$. Clearance from the body was accompanied with renal reabsorption of radioactivity. The kidney uptake of ${ }^{99 \mathrm{~m}} \mathrm{Tc}$ was 1.3 -fold higher at $1 \mathrm{~h}$ p.i., but at later time points ( 4 and $24 \mathrm{~h}$ p.i.), the renal retention of ${ }^{111}$ In was higher. Generally, the clearance rate of ${ }^{99 \mathrm{~m}} \mathrm{Tc}$ was higher than the clearance rate of ${ }^{111}$ In for the majority of organs; however, the difference was most pronounced at $24 \mathrm{~h}$ p.i. The most obvious observation was the difference in radioactivity uptake in liver and spleen. ${ }^{111}$ In uptake in these organs was 3.6-fold higher than ${ }^{99 \mathrm{~m}} \mathrm{Tc}$ at $4 \mathrm{~h}$ p.i., and the difference increased further at $24 \mathrm{~h}$ p.i.

Biodistribution of $\left[{ }^{99 m} \mathrm{Tc}(\mathrm{CO})_{3}\right]+-(\mathrm{HE})_{3}-Z_{I G F 1 R: 4551}$ in Balb/c nu/nu mice bearing $\mathrm{DU}-145$ prostate cancer xenografts. 
The biodistribution of $\left[{ }^{99 \mathrm{~m}} \mathrm{Tc}(\mathrm{CO})_{3}\right]^{+}-(\mathrm{HE})_{3}-\mathrm{Z}_{\mathrm{IGF1R}: 4551}$ at 4,8 and $24 \mathrm{~h}$ p.i. in mice bearing prostate cancer xenografts was also investigated and the results are presented in Figure 7. The tracer demonstrated a rapid first phase clearance from blood. Clearance of radioactivity from pancreas, stomach, colon and muscles was more rapid than clearance from tumour. Tumour-toblood, tumour-to-muscle and tumour-to-colon ratios had a tendency to increase from 4 to $8 \mathrm{~h}$ p.i. (Figure 8), but the difference was small. The results indicated that an optimal imaging time using $\left[{ }^{99 \mathrm{~m}} \mathrm{Tc}(\mathrm{CO})_{3}\right]^{+}-(\mathrm{HE})_{3}-\mathrm{Z}_{\mathrm{IGF} 1 \mathrm{R}: 4551}$ should be between 4 and $8 \mathrm{~h}$ after injection.

\section{Comparative biodistribution of $\left[^{99 m} \mathrm{Tc}(\mathrm{CO})_{3}\right]^{+}-(\mathrm{HE})_{3}-Z_{\text {IGF1R:4551 }}$ and ${ }^{111}$ In-DOTA-His $6^{-}$}

\section{$Z_{I G F I R: 4551}$ in Balb/c nu/nu mice bearing $D U-145$ prostate cancer xenografts.}

Data concerning comparative biodistribution in tumour-bearing mice at $6 \mathrm{~h}$ p.i. are presented in

Figures 9 and 10. The tumour uptake of both conjugates was significantly $(\mathrm{p}<0.00005)$ reduced by pre-saturation of IGF-1R receptors in tumours using non-labelled (HE) ${ }_{3}-Z_{\text {IGF1R:4551 }}$ (Figure 9), confirming the targeting specificity. Besides, pre-injection of a large excess of $(\mathrm{HE})_{3}-\mathrm{Z}_{\mathrm{IGF1R}: 4551}$ reduced significantly $(\mathrm{p}<0.05)$ uptake of both conjugates in lung, pancreas, stomach, and salivary gland. Reduction of uptake in colon was significant only for ${ }^{111}$ In- DOTA-

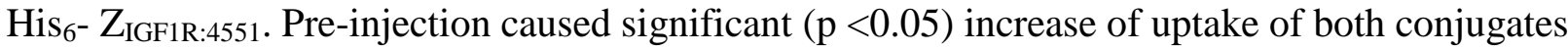
in kidneys. In the non-blocked group, uptake of $\left[{ }^{99 m} \mathrm{Tc}(\mathrm{CO})_{3}\right]^{+}-(\mathrm{HE})_{3}-\mathrm{Z}_{\mathrm{IGF} 1 \mathrm{R}: 4551}$ in tumours $(1.60 \pm 0.07 \% \mathrm{ID} / \mathrm{g})$ was significantly $(\mathrm{p}<0.005)$ higher than uptake of ${ }^{111}{ }^{\mathrm{In}-D O T A-\mathrm{His}_{6}-}$ $\mathrm{Z}_{\text {IGF1R:4551 }}(1.25 \pm 0.09 \% \mathrm{ID} / \mathrm{g})$. The ${ }^{111}$ In-labelled conjugate had significantly $(\mathrm{p}<0.05)$ higher uptake in liver, spleen, pancreas, and salivary gland. Tumour-to-organ ratios were significantly $(\mathrm{p}<0.05)$ higher for $\left[{ }^{99 \mathrm{~m}} \mathrm{Tc}(\mathrm{CO})_{3}\right]^{+}-(\mathrm{HE})_{3}-\mathrm{Z}_{\mathrm{IGF} 1 \mathrm{R}: 4551}$ in all organs except from bones.

\section{$\gamma$-camera imaging.}

Images acquired $6 \mathrm{~h}$ after administration of $\left[{ }^{99 \mathrm{~m}} \mathrm{Tc}(\mathrm{CO})_{3}\right]^{+}-(\mathrm{HE})_{3}-\mathrm{Z}_{\mathrm{IGF} 1 \mathrm{R}: 4551}$ to immunodeficient mice bearing subcutaneous DU-145 xenografts are presented in Figure 11. The xenografts were 
visualized and the tumour-to-contralateral site ratio was $3.9 \pm 0.1$. As predicted from the biodistribution studies described above, there was substantial accumulation of radioactivity in kidneys, liver and salivary glands, which were thereby clearly visualized. 


\section{DISCUSSION}

One of conclusion from clinical trials using IGF-1R-blocking monoclonal antibodies is that there is an urgent unmet clinical need for development of predictive biomarkers permitting patient selection for such therapy [28]. Pre-treatment concentration of IGF-1 in serum [12, 13], expression of IGF-1R in tumours, the level of circulating IGF-2 and IGF-binding proteins [12] have all been evaluated as predictors for response to IGF-1R targeting therapy in clinical trials. It was found that the level of membranous IGF-1R expression has a correlation with response rate to therapy using the antibody CP-751,871 [15]. Standard procedures for determination of biomarkers, such as sampling the blood and biopsy-based methods cannot appropriately address heterogeneity of target expression. In addition, repetitive invasive biopsy acquisition is preferably avoided. Pre-clinical data also suggest that the level of IGF-1R expression may change over time [29], as targeting therapy may cause a loss of receptor expression in cancer cell and induce tumour proliferation due to activation of other pathways. Such a switch is difficult to detect by biopsy-based methods. In contrast, radionuclide imaging may provide information on IGF-1R expression at different sites (including all metastases) in a single scan, from which conclusions about expression heterogeneity may be drawn. This non-invasive procedure can be performed repeatedly, to follow changes in expression level in response to therapy.

The use of a therapeutic antibody as a targeting agent is an obvious choice for radionuclide imaging. In this way, not only the level of a molecular target in the tumour, but also its accessibility to proposed therapy might be evaluated [16, 30, 31]. However, slow clearance from blood and organs in equilibrium with blood requires several (three-to-seven) days between injection of the probe and measurement, to obtain a reasonably high tumour-to-blood ratio. In contrast, the use of smaller targeting agents such as affibody molecules achieves the same tumour-to-blood ratio on the day of injection [22]. Still, the rapid clearance of small targeting proteins reduces their bioavailability, causing low absolute uptake in the tumour. To obtain a 
higher signal from the tumour, a higher injected activity would be desirable. However, the dosimetric properties of ${ }^{111} \mathrm{In}$, which was used for labelling of the first generation of anti-IGF-1R affibody molecules [22], put a limitation on the amount of injected radioactivity. The switch to ${ }^{99 \mathrm{~m}} \mathrm{Tc}$ in this study makes it possible to inject a higher dose of radioactivity due to appreciably shorter half-life and lower locally absorbed dose. Furthermore, properties of the gamma radiation emitted by ${ }^{99 \mathrm{~m}} \mathrm{Tc}$ permit the use of low energy collimators, which increases resolution and sensitivity of imaging. Thus, the use of ${ }^{99 \mathrm{~m}} \mathrm{Tc}$ is superior as a label for IGF-1R targeting affibody molecules compared to ${ }^{111} \mathrm{In}$.

Previous studies using a HER2-targeting affibody molecule suggest that the two most promising approaches for site-specific technetium labelling is to couple $\left[{ }^{99 \mathrm{~m}} \mathrm{Tc}(\mathrm{CO})_{3}\right]^{+}$to a histidine containing motif, for example the HEHEHE-tag [23], or to couple $(\mathrm{Tc}=\mathrm{O})^{3+}$ to a cysteinecontaining peptide-based chelator containing for example the motif GGGC at the C-terminus [32]. In both cases the chelator is built into the sequence of the targeting protein, which allows for production in a single biotechnological process excluding the need for further conjugation steps. For a construct containing the HEHEHE-tag, a convenient IMAC purification may be combined with low liver accumulation of radioactivity and the use of a GGGC motif as chelator causes low radioactivity accumulation in kidneys, but requires more complicated purification schemes during tracer production [33]. A combination of these approaches is tempting, but recent data suggest that $(\mathrm{Tc}=\mathrm{O})^{3+}$ coupling to the GGGC-motif in the presence of a HEHEHEtag in the probe is associated with the loss of site-specificity of labelling and poor control over biodistribution [34]. In this study, we therefore evaluated a labelling approach where $\left[{ }^{99 \mathrm{~m}} \mathrm{Tc}(\mathrm{CO})_{3}\right]^{+}$was conjugated to the HEHEHE-tag.

Affibody molecules represent a relatively new kind of targeting proteins. Although different factors influencing efficacy of radionuclide imaging are relatively well studied [20, 36 ], the 
majority of the parameters were obtained using derivatives of a single affibody variant, the antiHER2 $\mathrm{Z}_{\mathrm{HER} 2: 342}$ affibody molecule. It is not obvious that this information can be directly translated to development of other affibody molecules. However, the results of this study have shown that similar results may be obtained also with an affibody molecule binding to a different target, the IGF-1R. The introduction of a HEHEHE-tag permitted efficient production and purification of $\mathrm{Z}_{\mathrm{IGF1R}: 4551}$ while the high affinity to IGF-1R was retained according to SPRevaluation results (Figure 2C).

The SPR-evaluation of $Z_{\text {IGF1R:4551 }}$ binding to the human and mouse versions of IGF-1R showed that two parallel processes with different kinetics take place for both receptors (Figure 2C and D). The cell based binding in vitro assay showed also biphasic binding kinetics to the human receptor (Figure 4 B). This suggests that $\mathrm{Z}_{\mathrm{IGF1R}: 4551}$ binds to two different binding sites on IGF$1 \mathrm{R}$. This hypothesis is supported by the fact IGF-1R is a dimer with two binding sites, and the binding of the natural ligand, IGF-1, shows negative cooperativity [36]. The parental affibody molecule to $\mathrm{Z}_{\mathrm{IGF1R}: 4551}$ was phage-display selected to compete with the receptors natural ligand IGF-1 [37], and one could expect negative cooperativity also in this case.

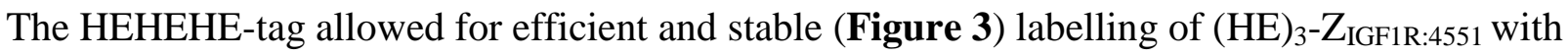
$\left[{ }^{99 \mathrm{~m}} \mathrm{Tc}(\mathrm{CO})_{3}\right]^{+}$using a commercial IsoLink kit. $\left[{ }^{99 \mathrm{~m}} \mathrm{Tc}(\mathrm{CO})_{3}\right]^{+}-(\mathrm{HE})_{3}-\mathrm{Z}_{\mathrm{IGF} 1 \mathrm{R}: 4551}$ has preserved binding specificity to IGF-1R (Figure 4) and low nanomolar affinity in binding to living IGF$1 \mathrm{R}$ expressing cells (Figure 5). An interesting feature of $\left[{ }^{99 \mathrm{~m}} \mathrm{Tc}(\mathrm{CO})_{3}\right]^{+}-(\mathrm{HE})_{3}-\mathrm{Z}_{\mathrm{IGF1R}: 4551}$ in comparison to anti-HER2 affibody molecules is its more rapid internalization by cancer cells (Figure 4). This suggests that the use of residualizing labels is desirable for efficient accumulation of radioactivity in the tumours. 
A direct double-label comparison of $\left[{ }^{99 \mathrm{~m}} \mathrm{Tc}(\mathrm{CO})_{3}\right]^{+}-(\mathrm{HE})_{3}-\mathrm{Z}_{\mathrm{IGF} 1 \mathrm{R}: 4551}$ and ${ }^{111}$ In-DOTA- His $66^{-}$ $\mathrm{Z}_{\text {IGF1R:4551 }}$ in NMRI mice demonstrated more favourable biodistribution of the ${ }^{99 \mathrm{~m}}$ Tc-labelled variant (Figure 6). Particularly, uptake in liver and spleen was nearly four-fold lower for ${ }^{99 \mathrm{~m}} \mathrm{Tc}$. Comparison of retention in liver and kidney suggested moderately residualizing properties of the $\left[{ }^{99 \mathrm{~m}} \mathrm{Tc}(\mathrm{CO})_{3}\right]^{+}-(\mathrm{HE})_{3}$ label.

The result of the biodistribution study in immunodeficient mice bearing DU-145 prostate cancer xenografts (Figure 7 and 8) demonstrated that an optimal imaging time for $\left[{ }^{99 \mathrm{~m}} \mathrm{Tc}(\mathrm{CO})_{3}\right]^{+}-$ $(\mathrm{HE})_{3}-\mathrm{Z}_{\mathrm{IGF1R}: 4551}$ is between 4 and $8 \mathrm{~h}$ p.i., i.e. on the same day as the injection. The targeting of tumours was IGF-1R-specific as demonstrated by the pre-saturation experiment in vivo (Figure 9). This experiment confirmed also IGF-1R- specific accumulation of radiolabelled Z in IGF-1R-expressing organs, such as lung, pancreas, stomach and salivary gland (Figure 9). This suggests that the murine model is adequate for studies on targeting of IGF-1R in vivo using $(\mathrm{HE})_{3}-\mathrm{Z}_{\text {IGF1R:4551 }}$ because it takes into account a specific interaction with host tissues. The suitability is further supported by the SPR analyses (Figure 2C and D), where the affinity of (HE) ${ }_{3}-Z_{\text {IGF1R:4551 }}$ for both the human and mouse receptors was found to be of comparable strength. Direct comparison with ${ }^{111}$ In-DOTA-His 6 -Z $\mathrm{Z}_{\mathrm{IGF1R}: 4551}$ was performed at $6 \mathrm{~h}$ p.i (Figure 9). $\left[{ }^{99 \mathrm{~m}} \mathrm{Tc}(\mathrm{CO})_{3}\right]^{+}-(\mathrm{HE})_{3}-\mathrm{Z}_{\mathrm{IGF} 1 \mathrm{R}: 4551}$ provided higher tumour-to-blood $(3.4 \pm 0.2$ versus $2.6 \pm 0.2 \%$, $\mathrm{p}<0.05)$ and tumour-to-muscle $(6.4 \pm 1.4$ versus $3.2 \pm 0.2, \mathrm{p}<0.05)$ ratios in a prostate cancer xenograft model (Figure 10). The use of ${ }^{99 \mathrm{~m}} \mathrm{Tc}$ - label instead of ${ }^{111} \mathrm{In}$ also significantly increased the tumour-to-lung, tumour-to-liver, tumour-to-spleen, tumour-to-pancreas, and tumour-tosalivary gland ratios (Figure 10).

In conclusion, the $\left[{ }^{99 \mathrm{~m}} \mathrm{Tc}(\mathrm{CO})_{3}\right]^{+}-(\mathrm{HE})_{3}-\mathrm{Z}_{\mathrm{IGF1R}: 4551}$ affibody molecule is a promising agent for visualization of IGF-1R in malignant tumours. Its use might enable patient stratification for IGF1R-targeting therapy making cancer treatment more personalized. 


\section{ACKNOWLEDGEMENT}

We would like to thank Tove Alm and Robert Karlsson for expert technical assistance when performing the binding measurements by SPR. This research was financially supported by grants from the Swedish Cancer Society (Cancerfonden), the Swedish Research Council (Vetenskapsrådet) and the Magn. Bergvall foundation. 


\section{REFERENCES}

1. Pollak MN, Schernhammer ES, Hankinson SE. Insulin-like growth factors and neoplasia. Nat Rev Cancer. 2004;4:505-18.

2. Nahta R, Yuan LX, Zhang B, Kobayashi R, Esteva FJ. Insulin-like growth factor-I receptor/human epidermal growth factor receptor 2 heterodimerization contributes to trastuzumab resistance of breast cancer cells. Cancer Res. 2005;65:11118-28.

3. Wu JD, Haugk K, Coleman I, Woodke L, Vessella R, Nelson P, Montgomery RB, Ludwig DL, Plymate SR. Combined in vivo effect of A12, a type 1 insulin-like growth factor receptor antibody, and docetaxel against prostate cancer tumors. Clin Cancer Res. 2006;12:6153-60.

4. Thomas F, Holly JM, Persad R, Bahl A, Perks CM. Fibronectin confers survival against chemotherapeutic agents but not against radiotherapy in DU145 prostate cancer cells: involvement of the insulin like growth factor-1 receptor. Prostate. 2010;70:856-65.

5. Harris LN, You F, Schnitt SJ, Witkiewicz A, Lu X, Sgroi D, Ryan PD, Come SE, Burstein HJ, Lesnikoski BA, Kamma M, Friedman PN, Gelman R, Iglehart JD, Winer EP. Predictors of resistance to preoperative trastuzumab and vinorelbine for HER2positive early breast cancer. Clin Cancer Res. 2007;13:1198-207.

6. Bruchim I, Attias Z, Werner H. Targeting the IGF1 axis in cancer proliferation. Expert Opin Ther Targets. 2009;13:1179-92.

7. Weroha SJ, Haluska P. IGF-1 receptor inhibitors in clinical trials--early lessons. J Mammary Gland Biol Neoplasia. 2008;13:471-83.

8. Rosenzweig SA, Atreya HS. Defining the pathway to insulin-like growth factor system targeting in cancer. Biochem Pharmacol. 2010;80:1115-24.

9. Chi KN, Bjartell A, Dearnaley D, Saad F, Schröder FH, Sternberg C, Tombal B, Visakorpi T. Castration-resistant prostate cancer: from new pathophysiology to new treatment targets. Eur Urol. 2009;56:594-605

10. Antonarakis ES, Carducci MA, Eisenberger MA. Novel targeted therapeutics for metastatic castration-resistant prostate cancer. Cancer Lett. 2010;291:1-13.

11. Pappo AS, Patel SR, Crowley J, Reinke DK, Kuenkele KP, Chawla SP, Toner GC, Maki RG, Meyers PA, Chugh R, Ganjoo KN, Schuetze SM, Juergens H, Leahy MG, Geoerger B, Benjamin RS, Helman LJ, Baker LH. R1507, a monoclonal antibody to the insulin-like growth factor 1 receptor, in patients with recurrent or refractory Ewing sarcoma family of tumors: results of a phase II Sarcoma Alliance for Research through Collaboration study. J Clin Oncol. 2011;29:4541-7.

12. Ramalingam SS, Spigel DR, Chen D, Steins MB, Engelman JA, Schneider CP, Novello S, Eberhardt WE, Crino L, Habben K, Liu L, Jänne PA, Brownstein CM, Reck M. Randomized phase II study of erlotinib in combination with placebo or R1507, a monoclonal antibody to insulin-like growth factor-1 receptor, for advanced-stage nonsmall-cell lung cancer. J Clin Oncol. 2011;29:4574-80. 
13. Juergens H, Daw NC, Geoerger B, Ferrari S, Villarroel M, Aerts I, Whelan J, Dirksen U, Hixon ML, Yin D, Wang T, Green S, Paccagnella L, Gualberto A. Preliminary efficacy of the anti-insulin-like growth factor type 1 receptor antibody figitumumab in patients with refractory Ewing sarcoma. J Clin Oncol. 2011;29:4534-40.

14. Huang F, Greer A, Hurlburt W, Han X, Hafezi R, Wittenberg GM, Reeves K, Chen J, Robinson D, Li A, Lee FY, Gottardis MM, Clark E, Helman L, Attar RM, Dongre A, Carboni JM. The mechanisms of differential sensitivity to an insulin-like growth factor1 receptor inhibitor (BMS-536924) and rationale for combining with EGFR/HER2 inhibitors. Cancer Res. 2009;69:161-70.

15. Gualberto A, C. L. Melvin, A. Dean, A. L. Ang, J. M. Reynolds, A. V. Lee, L. W. Terstappen, P. Haluska, A. Lipton and D. D. Karp, Characterization of NSCLC patients responding to anti-IGF-IR therapy. Journal of Clinical Oncology, 2008;

26(Supplement): 8000

16. Fleuren ED, Versleijen-Jonkers YM, van de Luijtgaarden AC, Molkenboer-Kuenen JD, Heskamp S, Roeffen MH, van Laarhoven HW, Houghton PJ, Oyen WJ, Boerman OC, van der Graaf WT. Predicting IGF-1R therapy response in bone sarcomas: immunoSPECT imaging with radiolabeled R1507. Clin Cancer Res. 2011;17:7693-703.

17. Cornelissen B, McLarty K, Kersemans V, Reilly RM. The level of insulin growth factor-1 receptor expression is directly correlated with the tumor uptake of (111)In-IGF$1(\mathrm{E} 3 \mathrm{R})$ in vivo and the clonogenic survival of breast cancer cells exposed in vitro to trastuzumab (Herceptin). Nucl Med Biol. 2008;35:645-53.

18. Cao L, Yu Y, Darko I, Currier D, Mayeenuddin LH, Wan X, Khanna C, Helman LJ. Addiction to elevated insulin-like growth factor I receptor and initial modulation of the AKT pathway define the responsiveness of rhabdomyosarcoma to the targeting antibody. Cancer Res. 2008;68:8039-48.

19. Zha J, O'Brien C, Savage H, Huw LY, Zhong F, Berry L, Lewis Phillips GD, Luis E, Cavet G, Hu X, Amler LC, Lackner MR. Molecular predictors of response to a humanized anti-insulin-like growth factor-I receptor monoclonal antibody in breast and colorectal cancer. Mol Cancer Ther. 2009;8:2110-21.

20. Ahlgren S, Tolmachev V. Radionuclide molecular imaging using Affibody molecules. Curr Pharm Biotechnol. 2010;11:581-9.

21. Baum RP, Prasad V, Müller D, Schuchardt C, Orlova A, Wennborg A, Tolmachev V, Feldwisch J. Molecular imaging of HER2-expressing malignant tumors in breast cancer patients using synthetic $111 \mathrm{In}$ - or 68Ga-labeled affibody molecules. J Nucl Med. 2010;51:892-7.

22. Tolmachev V, Malmberg J, Hofström C, Abrahmsén L, Bergman T, Sjöberg A, Sandström M, Gräslund T, Orlova A. Imaging of IGF-1R in prostate cancer xenografts using the Affibody molecule 111In-DOTA-Z IGF1R:4551. J Nucl Med. 2012;53:14653.

23. Tolmachev V, Hofström C, Malmbeg J, Ahlgren S, Hosseinimehr SJ, Sandström M, Abrahmsén L, Orlova A, Gräslund T. HEHEHE-tagged affibody molecule may be purified by IMAC, is conveniently labeled with $\left[{ }^{99}(\mathrm{~m}) \mathrm{Tc}(\mathrm{CO})_{3}\right](+)$, and shows 
improved biodistribution with reduced hepatic radioactivity accumulation. Bioconjug Chem, 2010; 21:2013-2022.

24. Hofström C, Orlova A, Altai M, Wångsell F, Gräslund T, Tolmachev V. The use of a HEHEHE-purification tag improves biodistribution of Affibody molecules sitespecifically labeled with $99 \mathrm{mTc}, 111 \mathrm{In}$ and $125 \mathrm{I}$ compared to a hexahistidine-tag. J Med Chem. 2011;54:3817-3826.

25. Lundberg E, Höidén-Guthenberg I, Larsson B, Uhlén M, Gräslund T. Site-specifically conjugated anti-HER2 Affibody molecules as one-step reagents for target expression analyses on cells and xenograft samples. J Immunol Methods. 2007;319:53-63.

26. Björkelund H, Gedda L, Barta P, Malmqvist M, Andersson K. Gefitinib induces epidermal growth factor receptor dimers which alters the interaction characteristics with ${ }^{125}$ I-EGF. PLoS One. 2011;6:e24739.

27. Orlova A, Nilsson FY, Wikman M, Widström C, Ståhl S, Carlsson J, Tolmachev V. Comparative in vivo evaluation of technetium and iodine labels on an anti-HER2 affibody for single-photon imaging of HER2 expression in tumors. J Nucl Med. 2006:47:512-519.

28. Olmos D, Martins AS, Jones RL, Alam S, Scurr M, Judson IR. Targeting the InsulinLike Growth Factor 1 Receptor in Ewing's Sarcoma: Reality and Expectations. Sarcoma. 2011;2011:402508.

29. Huang F, Hurlburt W, Greer A, Reeves KA, Hillerman S, Chang H, Fargnoli J, Graf Finckenstein F, Gottardis MM, Carboni JM. Differential mechanisms of acquired resistance to insulin-like growth factor-i receptor antibody therapy or to a smallmolecule inhibitor, BMS-754807, in a human rhabdomyosarcoma model. Cancer Res. 2010;70:7221-31.

30. van Dongen GA, Visser GW, Lub-de Hooge MN, de Vries EG, Perk LR. Immuno-PET: a navigator in monoclonal antibody development and applications. Oncologist. 2007;12:1379-89.

31. Heskamp S, van Laarhoven HW, Molkenboer-Kuenen JD, Franssen GM, VersleijenJonkers YM, Oyen WJ, van der Graaf WT, Boerman OC. ImmunoSPECT and immunoPET of IGF-1R expression with the radiolabeled antibody R1507 in a triplenegative breast cancer model. J Nucl Med. 2010;51:1565-72.

32. Wållberg H, Orlova A, Altai M, Hosseinimehr SJ, Widström C, Malmberg J, Ståhl S, Tolmachev V. Molecular design and optimization of 99mTc-labeled recombinant affibody molecules improves their biodistribution and imaging properties. J Nucl Med. 2011;52:461-9.

33. Wållberg H, Löfdahl PK, Tschapalda K, Uhlén M, Tolmachev V, Nygren PK, Ståhl S. Affinity recovery of eight HER2-binding affibody variants using an anti-idiotypic affibody molecule as capture ligand. Protein Expr Purif. 2011;76:127-35.

34. Lindberg H, Hofström C, Altai M, Honorvar H, Wållberg H, Orlova A, Ståhl S, Gräslund T, Tolmachev V. Evaluation of a HER2-targeting affibody molecule 
combining an N-terminal HEHEHE-tag with a GGGC chelator for (99m)Tc-labelling at the $\mathrm{C}$ terminus. Tumour Biol. 2012;33:641-51.

35. Tolmachev V, Orlova A. Influence of labelling methods on biodistribution and imaging properties of radiolabelled peptides for visualisation of molecular therapeutic targets. Curr Med Chem. 2010;17:2636-55.

36. Surinya KH, Forbes BE, Occhiodoro F, Booker GW, Francis GL, Siddle K, Wallace JC, Cosgrove LJ. An investigation of the ligand binding properties and negative cooperativity of soluble insulin-like growth factor receptors. J Biol Chem. 2008;283:5355-63.

37. Li J, Lundberg E, Vernet E, Larsson B, Höidén-Guthenberg I, Gräslund T. Selection of affibody molecules to the ligand-binding site of the insulin-like growth factor-1 receptor. Biotechnol Appl Biochem. 2010;55:99-109. 


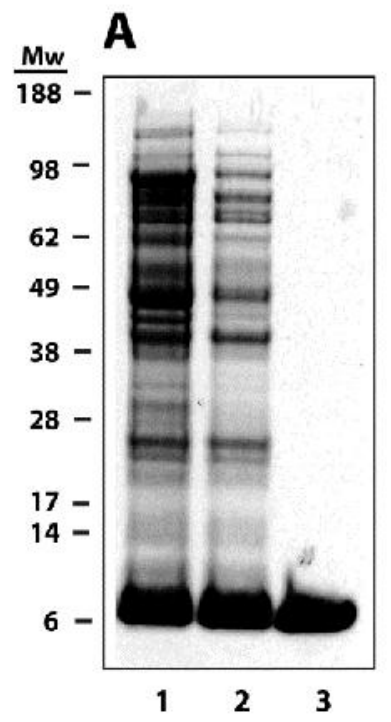

B
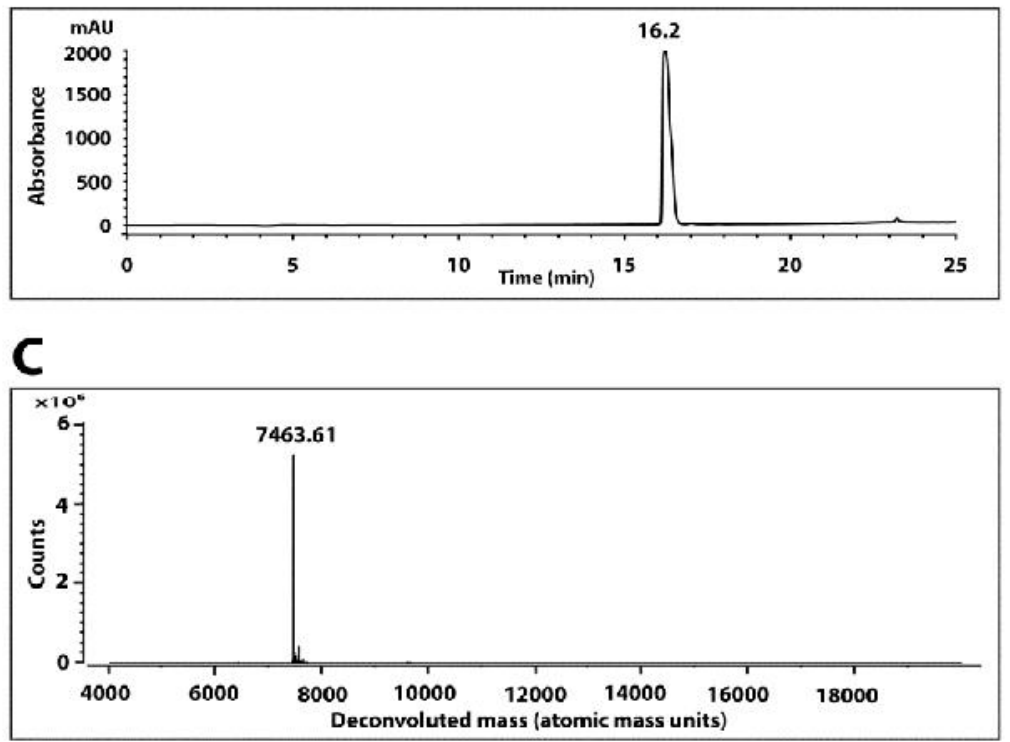

Figure 1. Purification and characterization of (HE) ${ }_{3}-Z_{\mathrm{IGF1R}: 4551}$. Panel A represents an SDSPAGE analysis of samples taken during the purification procedure: (1) sample taken after cell lysis, (2) sample taken after heat treatment for 10 minutes at $60^{\circ} \mathrm{C}$, (3) sample taken after purification by IMAC and RP-HPLC. Panel B represents an RP-HPLC analysis of purified $(\mathrm{HE})_{3}-\mathrm{Z}_{\mathrm{IGF1R}: 4551}$ where the $\mathrm{x}$-axis corresponds to time after injection and the y-axis corresponds to measured absorbance at $220 \mathrm{~nm}$. Panel $\mathrm{C}$ represents the mass spectrum of purified $(\mathrm{HE})_{3^{-}}$ $\mathrm{Z}_{\mathrm{IGF1R}: 4551}$ where the $\mathrm{x}$-axis corresponds to deconvoluted atomic mass and the y-axis corresponds to the number of events. 
A

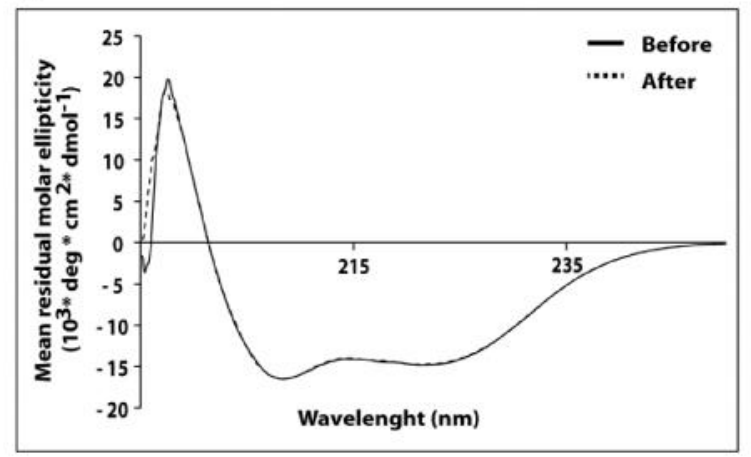

C

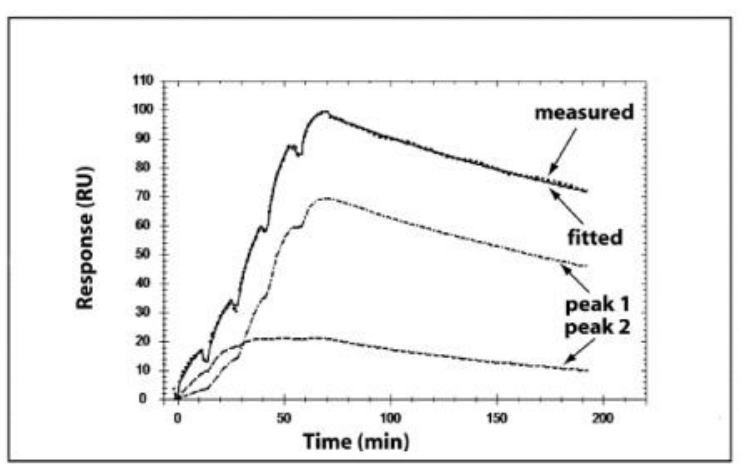

B

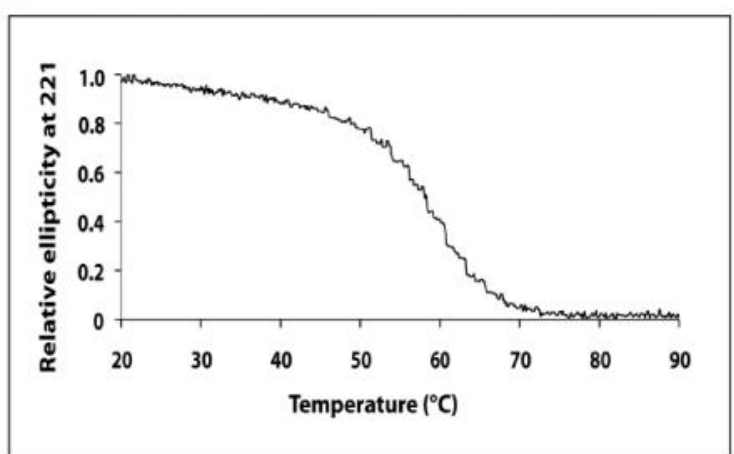

D

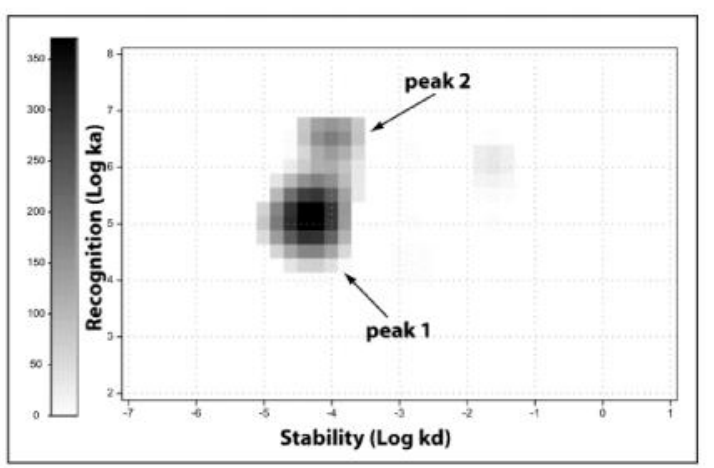

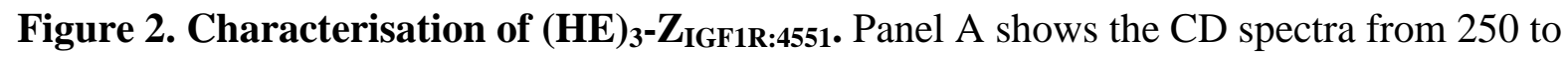
$190 \mathrm{~nm}$ for $(\mathrm{HE})_{3}-\mathrm{Z}_{\mathrm{IGF1R}: 4551}$ before and after heating from $20^{\circ} \mathrm{C}$ to $90^{\circ} \mathrm{C}$. Panel B shows the normalized relative ellipticity of (HE) $)_{3}-Z_{\text {IGF1R:4551 }}$ at $221 \mathrm{~nm}$ as a function of temperature. Panel $\mathrm{C}$ shows the biosensor analysis of (HE) $)_{3} \mathrm{Z}_{\mathrm{IGF1R}: 4551}$. "Measured" represents the experimentally obtained curve. Interaction Map analysis (Panel D) revealed two well defined processes (Peak 1 and Peak 2 in panels C and D). The sum of peak 1 and 2 is shown in Panel C as "fitted", which may be hard to distinguish since it is on top of the measured curve. 


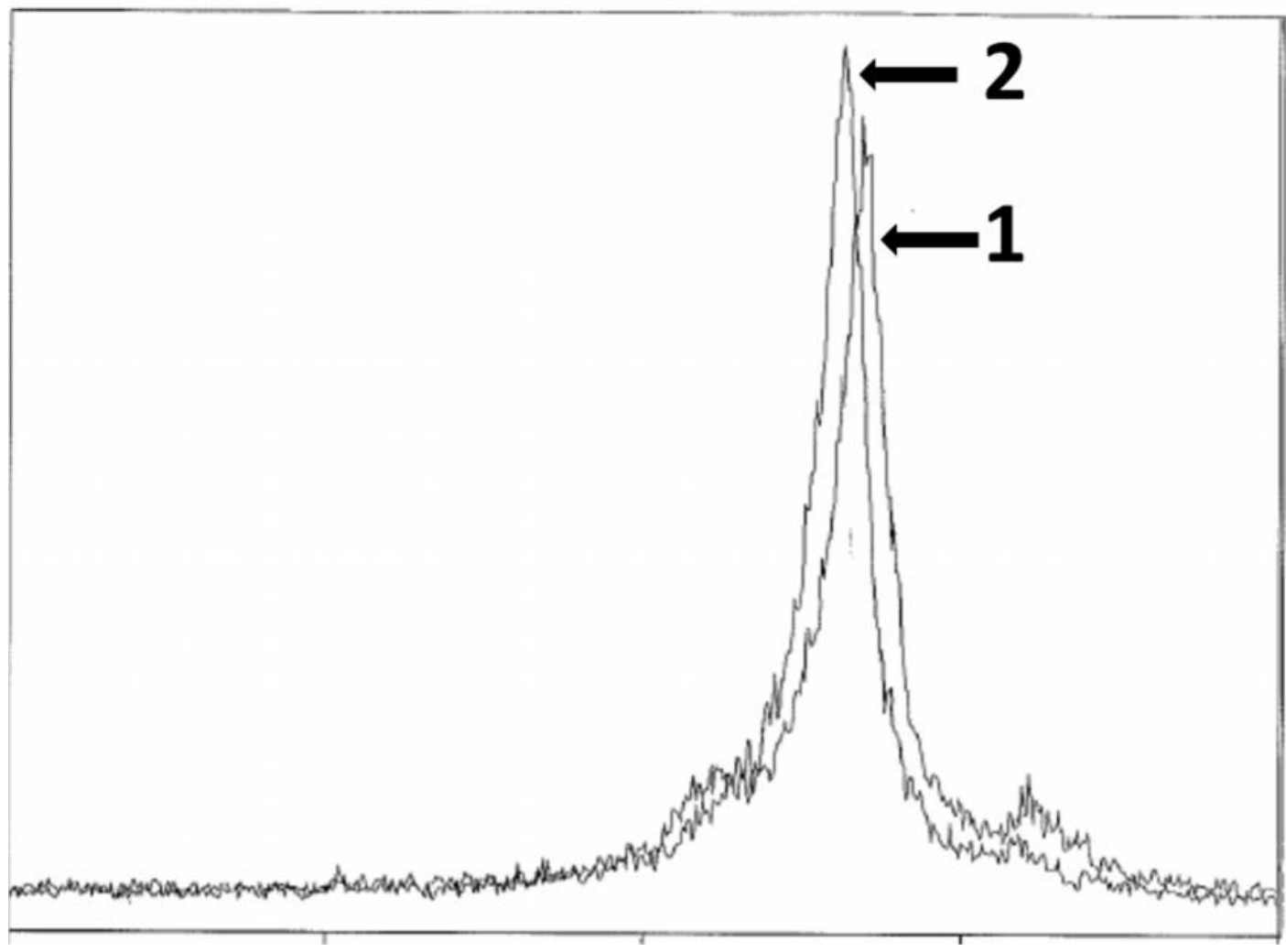

Figure 3. SDS-PAGE analysis of $\left[{ }^{99 \mathrm{~m}} \mathrm{Tc}(\mathrm{CO})_{3}\right]^{+}-(\mathrm{HE})_{3}-\mathrm{Z}_{\mathrm{IGF1R}: 4551}$ stability in serum. Distribution of radioactivity along lanes was visualized and quantified using Cyclone ${ }^{\mathrm{TM}}$ Storage Phosphor System. 1. [ $\left.{ }^{99 \mathrm{~m}} \mathrm{Tc}(\mathrm{CO})_{3}\right]^{+}-(\mathrm{HE})_{3}-\mathrm{Z}_{\mathrm{IGF} 1 \mathrm{R}: 4551}$ sample, which was incubated in murine serum at $37^{\circ} \mathrm{C}$ for 1 h. 2 . [ $\left.{ }^{99 \mathrm{~m}} \mathrm{Tc}(\mathrm{CO})_{3}\right]^{+}-(\mathrm{HE})_{3}-\mathrm{Z}_{\mathrm{IGF1R}: 4551}$ sample, which was incubated in PBS at room temperature for $1 \mathrm{~h}$. 

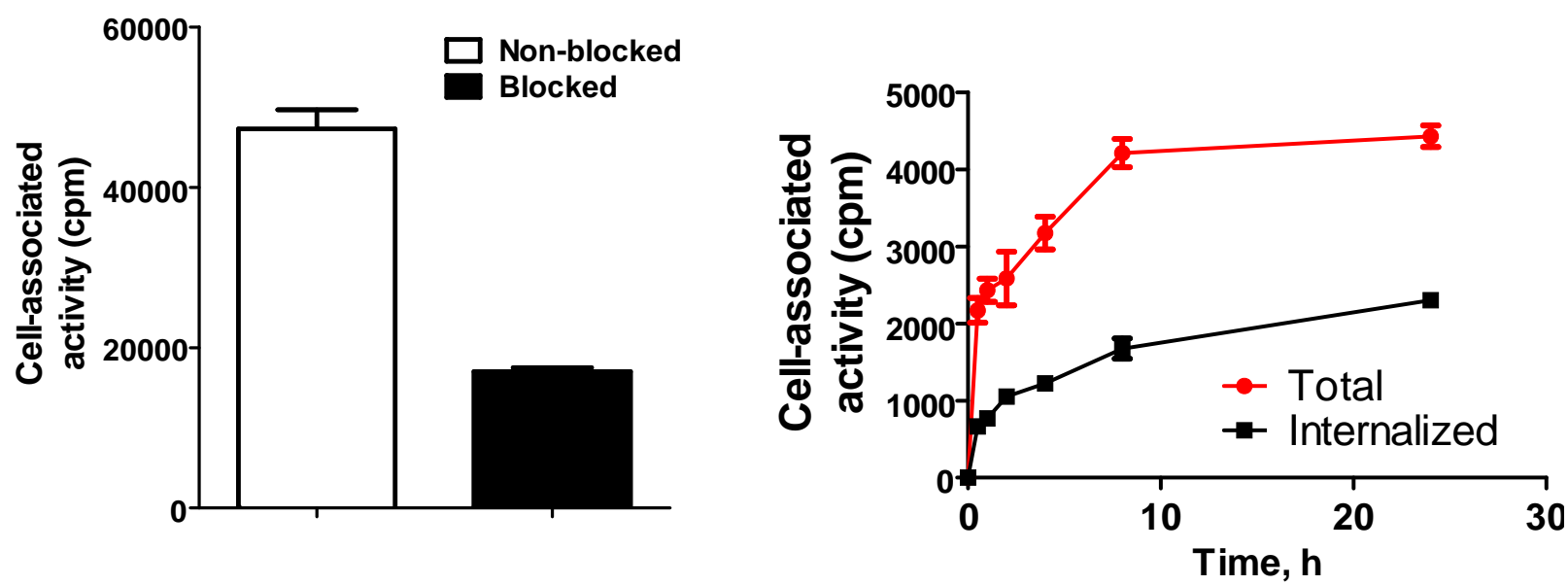

Figure 4. In vitro characterization of $\left[{ }^{99 \mathrm{~m}} \mathrm{Tc}(\mathrm{CO})_{3}\right]^{+}-(\mathrm{HE})_{3}-\mathrm{Z}_{\mathrm{IGF} 1 \mathrm{R}: 4551}$. A. Binding specificity of $\left[{ }^{99 \mathrm{~m}} \mathrm{Tc}(\mathrm{CO})_{3}\right]^{+}-(\mathrm{HE})_{3}-\mathrm{Z}_{\mathrm{IGF1R}: 4551}$ affibody molecules to IGF-1R expressing DU-145 cells. For the pre-saturation of IGF-1R, a 100-fold molar excess of non-radioactive (HE) ${ }_{3}$-Z IGF1R:4551 affibody molecule was added. Data are presented as mean values from three cell dishes \pm SD. B. Binding and internalization of $\left[{ }^{99 \mathrm{~m}} \mathrm{Tc}(\mathrm{CO})_{3}\right]^{+}-(\mathrm{HE})_{3}-\mathrm{Z}_{\mathrm{IGF1R}: 4551}$ by prostate cancer DU-145 cell line. Cells were incubated with $\left[{ }^{99 \mathrm{~m}} \mathrm{Tc}(\mathrm{CO})_{3}\right]^{+}-(\mathrm{HE})_{3}-\mathrm{Z}_{\mathrm{IGF} 1 \mathrm{R}: 4551}$ at $37^{\circ} \mathrm{C}$. Data presented as mean values from three cell dishes \pm SD. Error bars might be not seen because they are smaller than the symbols. 


\section{DU145 cells}

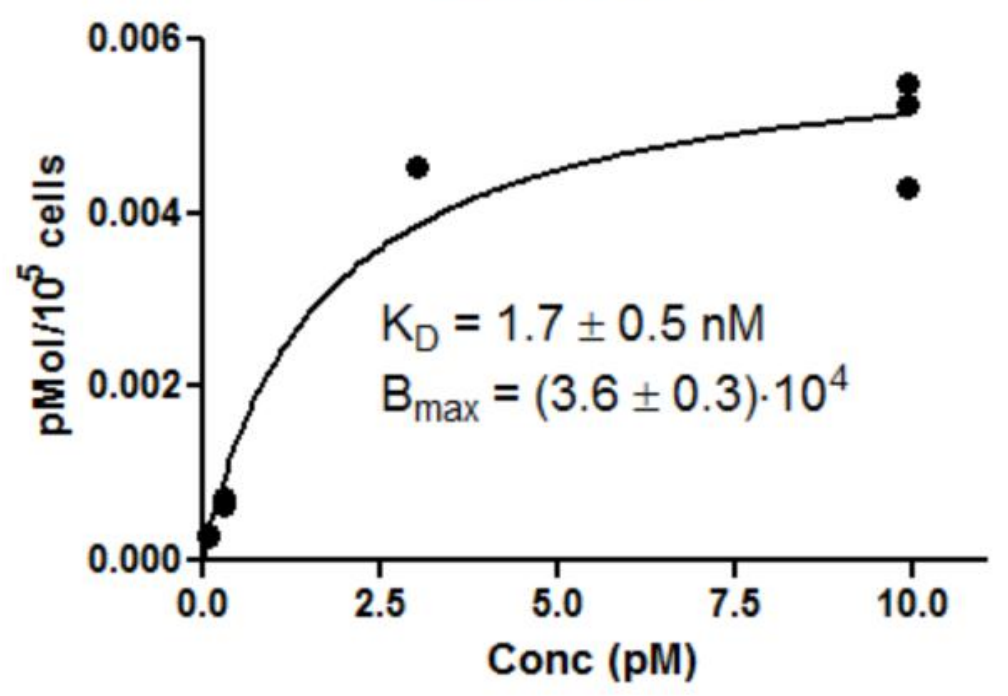

Figure 5. Affinity determination of $\left[{ }^{99 \mathrm{~m}} \mathrm{Tc}(\mathrm{CO})_{3}\right]^{+}-(\mathrm{HE})_{3}-\mathrm{Z}_{\mathrm{IGF} 1 \mathrm{R}: 4551}$ binding to living DU-145 cells. Cells were incubated (in triplicates) with different concentrations of $\left[{ }^{99 \mathrm{~m}} \mathrm{Tc}(\mathrm{CO})_{3}\right]^{+}-(\mathrm{HE})_{3^{-}}$ $\mathrm{Z}_{\mathrm{IGF1R}: 4551}$, followed by washing and radioactivity measurements. The cell-bound radioactivity was corrected for unspecific binding and plotted as a function of the concentration of $\left[{ }^{99 \mathrm{~m}} \mathrm{Tc}(\mathrm{CO})_{3}\right]^{+}-(\mathrm{HE})_{3}-\mathrm{Z}_{\mathrm{IGF} 1 \mathrm{R}: 4551}$. 


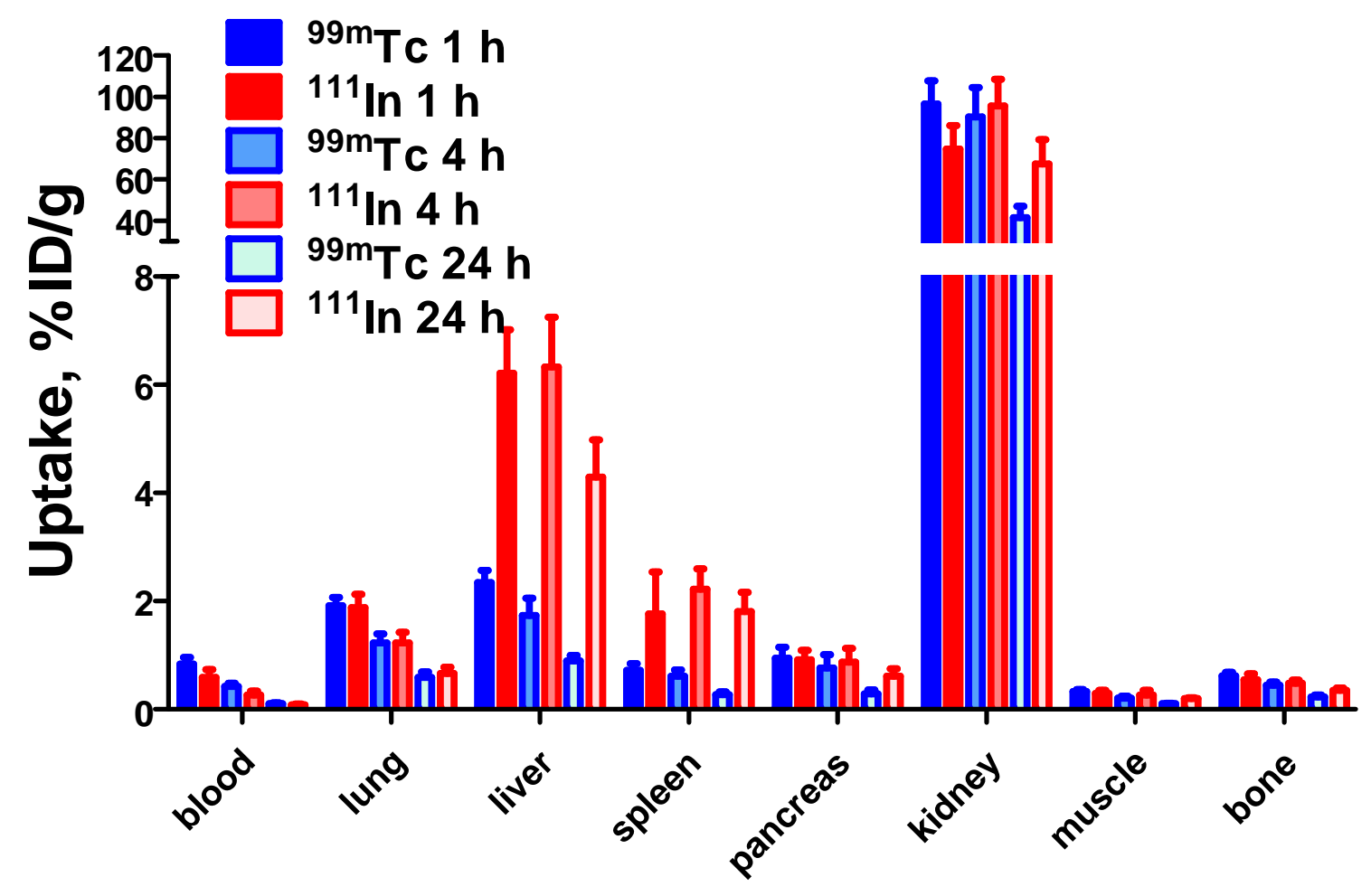

Figure 6. Comparative biodistribution of $\left[{ }^{99 \mathrm{~m}} \mathrm{Tc}(\mathrm{CO})_{3}\right]^{+}-(\mathrm{HE})_{3}-\mathrm{Z}_{\mathrm{IGF} 1 \mathrm{R}: 4551}$ and ${ }^{111}{ }^{\mathrm{In}-\mathrm{DOTA}} \mathrm{His}_{6}{ }^{-}$

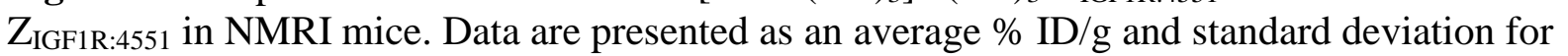
four mice. The total injected $\mathrm{Z}_{\mathrm{IGF1R}: 4551}$ dose per mouse was $0.13 \mathrm{nmol}$. 


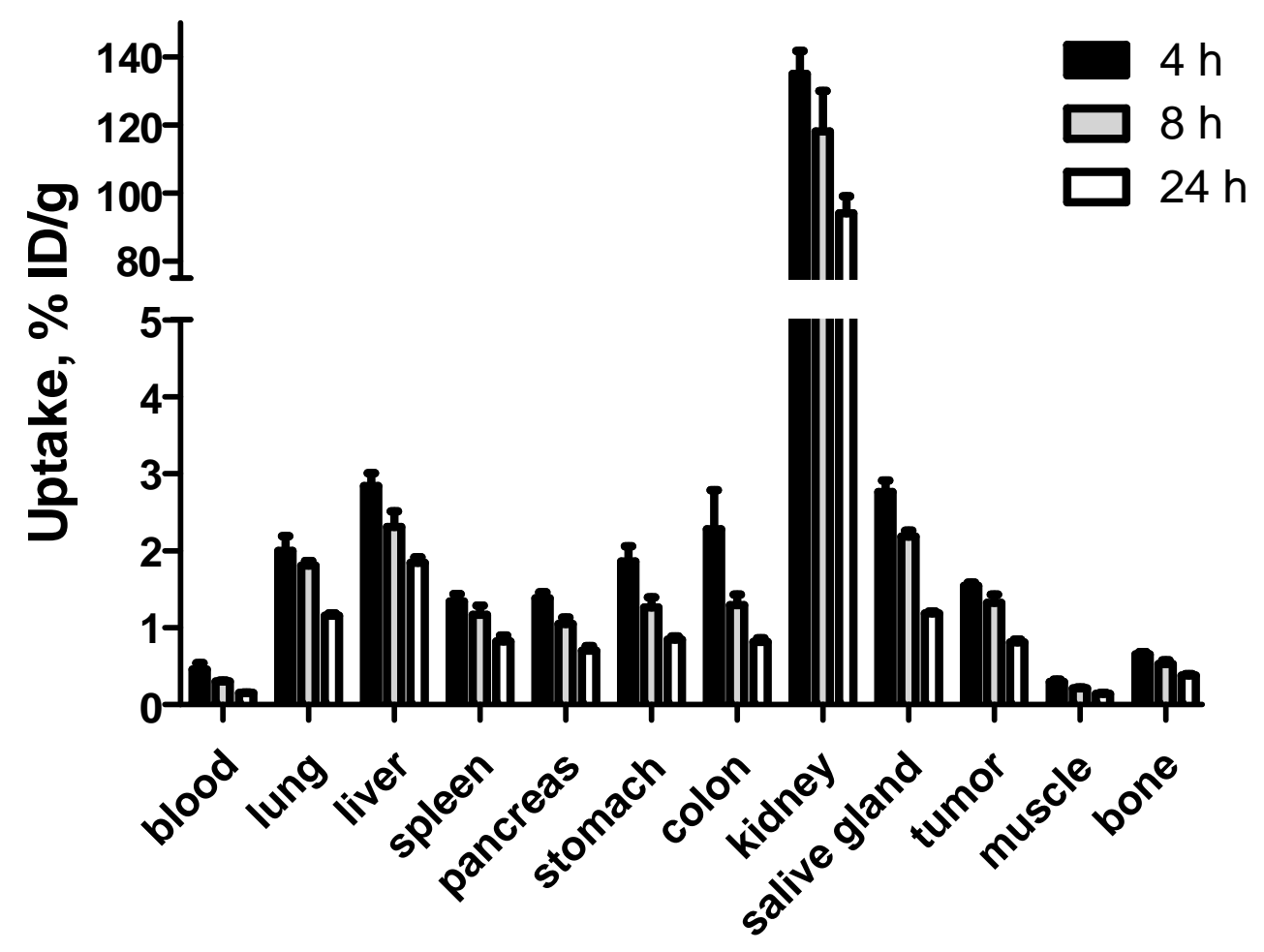

Figure 7. Biodistribution of $\left[{ }^{99 \mathrm{~m}} \mathrm{Tc}(\mathrm{CO})_{3}\right]^{+}-(\mathrm{HE})_{3}-\mathrm{Z}_{\mathrm{IGF1R}: 4551}$ (injected dose $0.13 \mathrm{nmol}$ ) in male $\mathrm{Balb} / \mathrm{c}$ nu/nu mice with subcutaneous DU-145 xenografts at different time points. Values are presented as mean \% ID/g and error-bars correspond to SD $(n=4)$. 


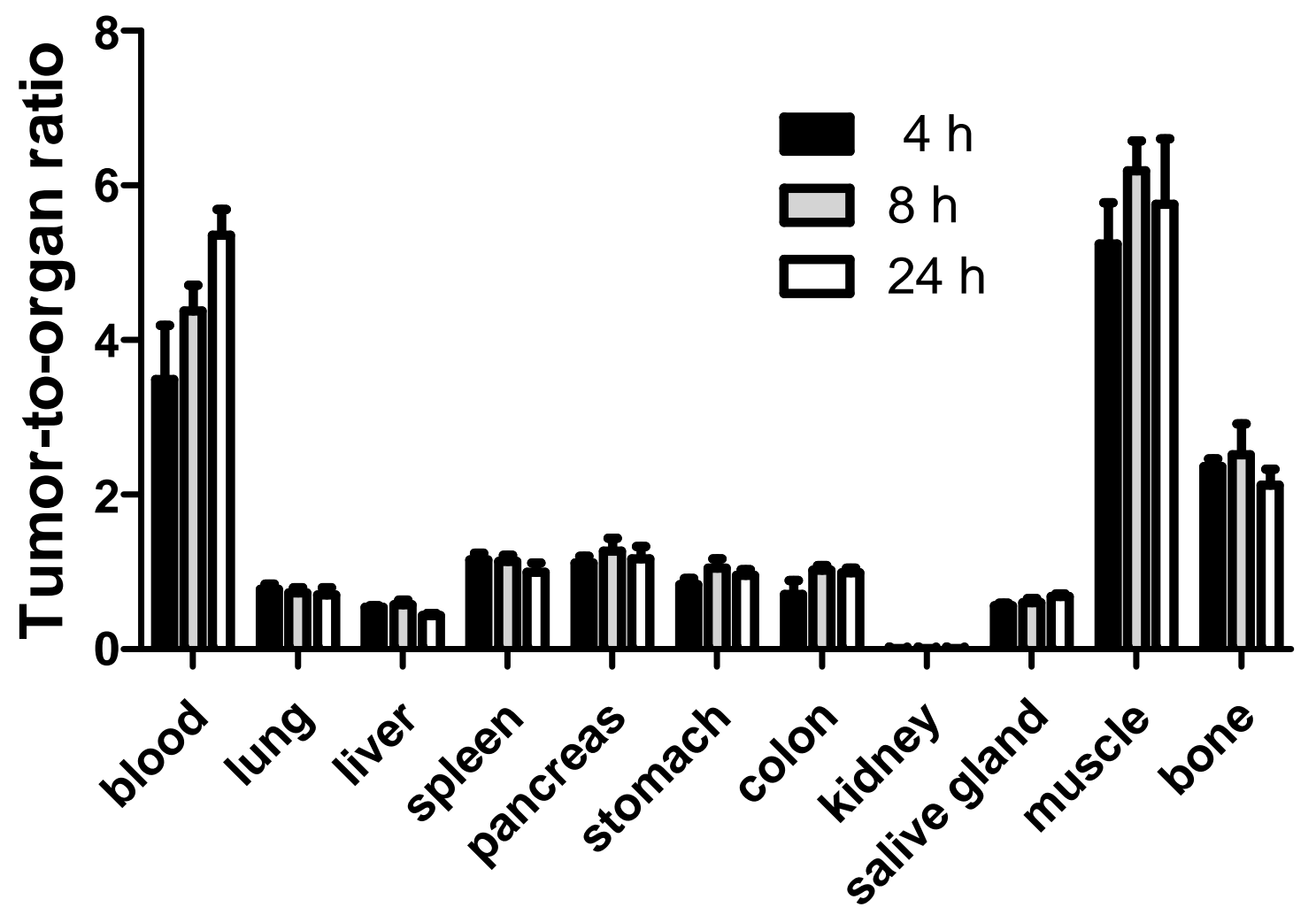

Figure 8. Tumour-to-organ ratios for $\left[{ }^{99 \mathrm{~m}} \mathrm{Tc}(\mathrm{CO})_{3}\right]^{+}-(\mathrm{HE})_{3}-\mathrm{Z}_{\text {IGFIR:4551 }}$ (injected dose $0.13 \mathrm{nmol}$ ) in male Balb/c nu/nu mice with subcutaneous DU-145 xenografts at different time points. Values are presented as mean $\% \mathrm{ID} / \mathrm{g}$ and the error-bars correspond to $\mathrm{SD}(\mathrm{n}=4)$. 
Fig.9 Comparative biodistribution of $\left[{ }^{99 \mathrm{~m}} \mathrm{Tc}(\mathrm{CO})_{3}\right]^{+}-(\mathrm{HE})_{3}-\mathrm{Z}_{\mathrm{IGF1R}: 4551}$ and ${ }^{111}$ In-DOTA- His $6^{-}$ $\mathrm{Z}_{\mathrm{IGF1R}: 4551}$ in male Balb/c nu/nu mice with subcutaneous DU-145 xenografts with and without pre-injection of non-labelled $(\mathrm{HE})_{3}-\mathrm{Z}_{\mathrm{IGF1R}: 4551}$. Data are presented as mean \%ID/g and error-bars correspond to $\operatorname{SD}(n=4)$.

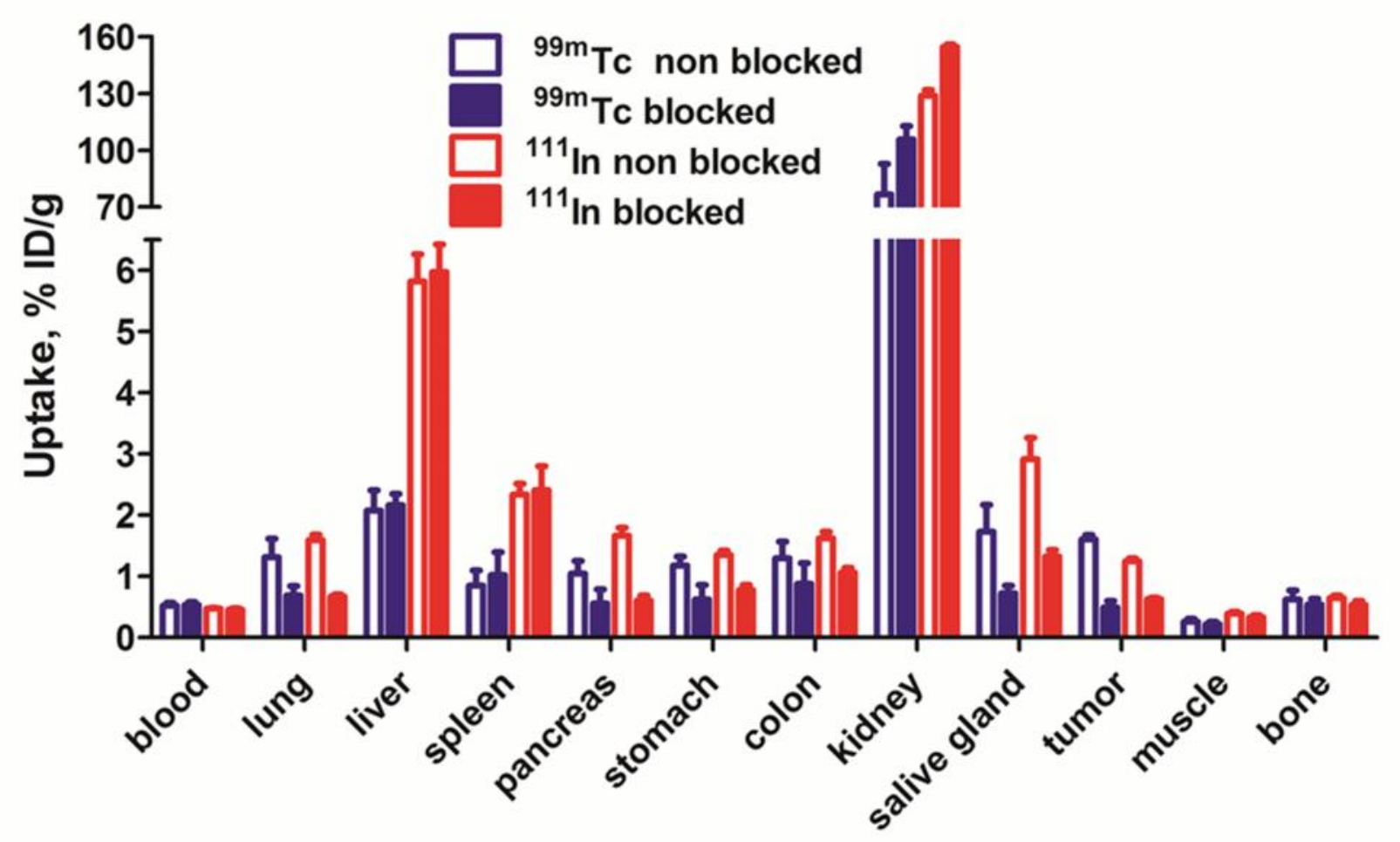


Fig.10 Tumour-to-organ ratios for $\left[{ }^{99 \mathrm{~m}} \mathrm{Tc}(\mathrm{CO})_{3}\right]^{+}-(\mathrm{HE})_{3}-\mathrm{Z}_{\text {IGF1R:4551 }}$ and ${ }^{111}$ In-DOTA- His $6^{-}$

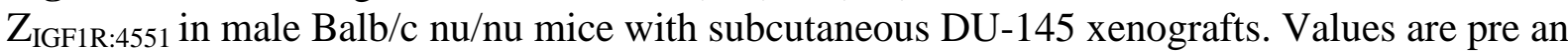
average and standard deviation for four mice.

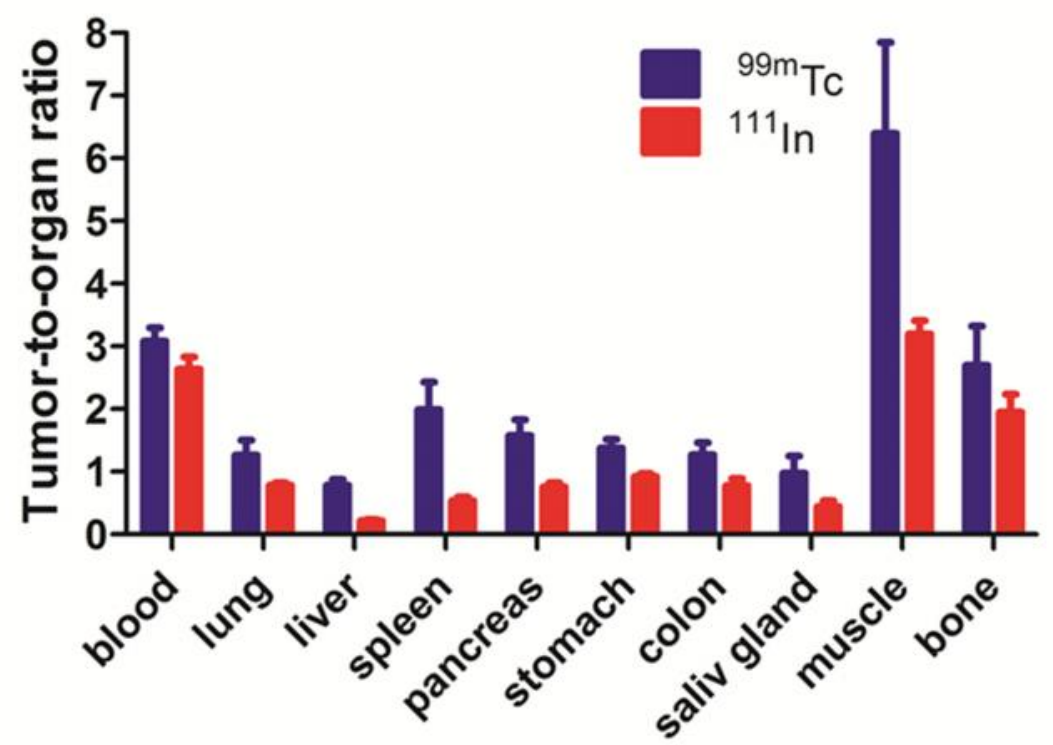



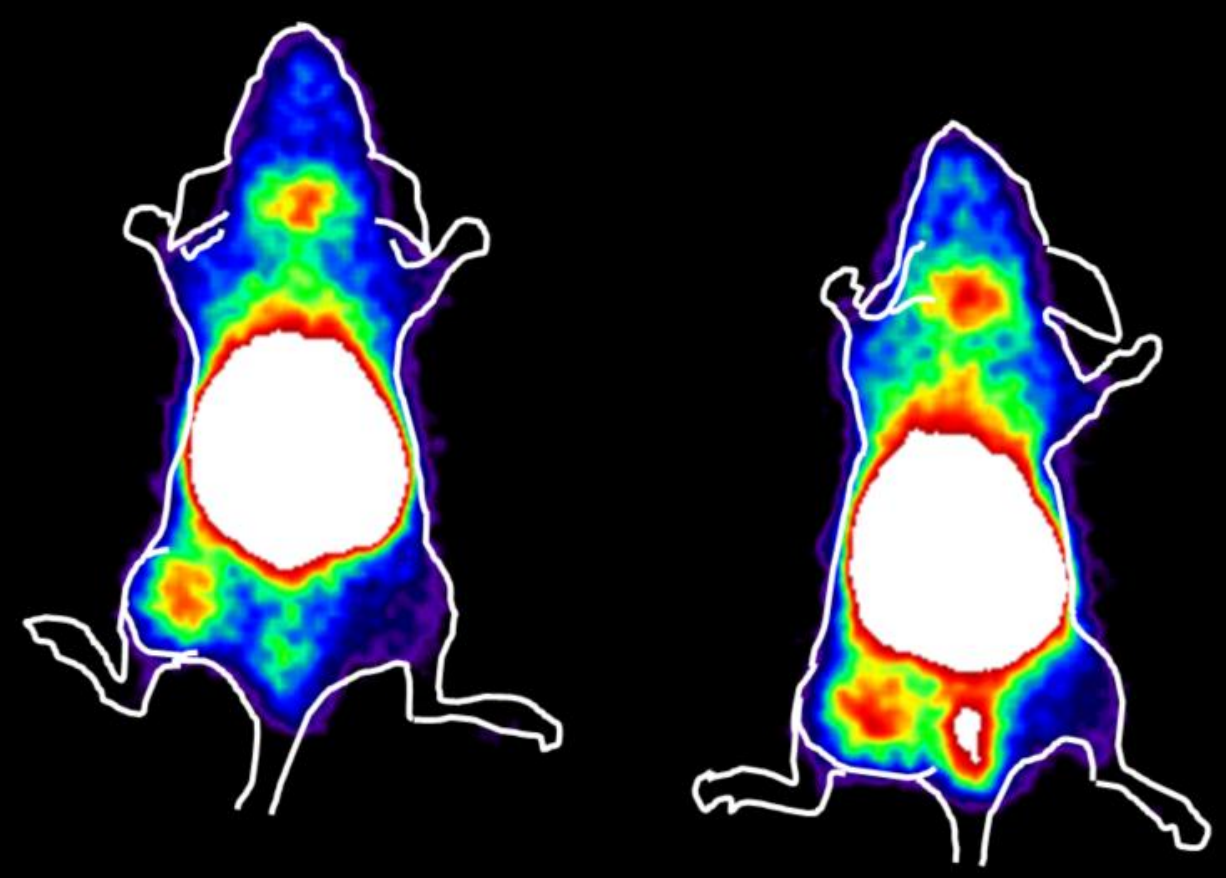

Figure 11. Imaging of IGF-1R expression in DU-145 prostate cancer xenografts in Balb/c nu/nu mice using $\left[{ }^{99 \mathrm{~m}} \mathrm{Tc}(\mathrm{CO})_{3}\right]^{+}-(\mathrm{HE})_{3}-\mathrm{Z}_{\mathrm{IGF1R}: 4551}$. Planar gamma-camera images were acquired $6 \mathrm{~h}$ after injection. 